\title{
DE VERBREIDING VAN HET MATRIARCHAAT OP SUMATRA
}

D O O R

DR. G. A. W I L K E N.

In onze verhandeling "Over de verwantschap en het huwelijksen erfrecht bij de volken van het Maleische ras" ${ }^{\mathbf{1}}$, hebben wij uitvoerig gesproken over het matriarchat bij de Maleiers van de Padangsche Bovenlanden, bepaaldelijk van de landschappen Agam, I Kota en Tanah-Datar 2. Gelijk echter bekend is, wordt, behalve de Padangsche Bovenlanden, nog een belangrijk deel van Sumatra, en wel het stroomgebied van al de groote naar de Oostkust vloeiende rivieren, de Moesi, Djambi, Indragiri, Kampar, Siak en Rokan, door Maleiers bewoond. Het is ons doel in de volgende bladzijden in de eerste plaats na te gaan, in hoeverre ook bij deze Maleiers het matriarchaat gevonden wordt. Beginnen wij daartoe met het stroomgebied van de Kampar, om vervolgens de Noordelijk daarvan gelegen Siak- en Rokan-landen te beschouwen, en daarna over te gaan tot de streken ten Zuiden van genoemde rivier, welke door de Indragiri, Djambi en Moesi worden bespoeld.

De Kampar, ook wel Kampar-Bĕsar of de groote Kampar geheeten, ontstaat uit de samenvloeiing van twee kleinere rivieren, die de Kampar-Kanan en de Kampar-Kiri (dat is, naar de letterlijke beteekenis, de rechter- en linker-, maar naar ons spraakgebruik de linker- en rechter-Kampar) genoemd worden. Het bovenstroomgebied van de Kampar-Kanan omvat eenige federaties van kota's of dorpen, geschoeid op de leest van dergelijke kota-vereenigingen in de $\mathrm{Pa}$ -

1 Opgenomen in het tijdschrift "De Indische Gids", jaarg. 1883, dl. I, blz. 656-764, ook afzonderlijk verschenen bij De Bussy, Amsterdam, 1883. Naar deze afzonderlijke uitgave zal in dit opstel worden geciteerd.

${ }^{2}$ O. c., blz. 24 vv. 
dangsche Bovenlanden. Evenals daar, zijn ook hier de federaties geheeten naar het aantal kota's, welke zich samengevoegd hebben ${ }^{3}$. Het Westelijkste landschap aan de Kampar-Kanan is Gloegoer VI Kota, uit twee federaties bestaande, namelijk Gloegoer III Kota di-moediq en Gloegoer III Kota di-ilir, waarvan de eerste, gelijk de naam dit vanzelf aanduidt, bovenstrooms, de andere benedenstrooms gelegen is ${ }^{4}$. $\mathrm{Na}$ dit landschap van haren oorsprong af in eene richting van het Westen naar het Oosten te hebben doorloopen, komt de Kampar-Kanan in het gebied van de federatie Kamparnan XII Kota, ook wel XII Kota Kampar geheeten 5. Oostelijk hiervan strekken zich de Kampar nan V Kota of V Kota Kampar uit, eene vereeniging van vijf dorpen. Ten Zuiden van de XII Kota Kampar heeft men nog het landschap Pangkalan, ter onderscheiding van andere streken van denzelfden naam meer Oostelijk in het stroomgebied van de Kampar-Kiri gelegen, meestal Pangkalan-Kota-Baroe of Pangkalan VI Kota genoemd, welk landschap eerst in eene Oostelijke, dan in bijna Noordelijke richting doorstroomd wordt door de Mahi, een rechtertak van de Kampar-Kanan. Al deze landschappen zijn achtereenvolgens in 1879,1881 en 1882 bij het Gouvernementsgebied ingelijfd ${ }^{\mathbf{6}}$, met uitzondering van de V Kota, welke nog onafhankelijk zijn. - Oostelijk van de V Kota vindt men het eveneens nog onafhankelijke dorpsstaatje Kampar benevens het plaatsje Taratak-Boeloeh, dat eene onderhoorigheid is van den sultan van Siak. - De landschappen aan de Kampar-Kiri, die eveneens nog niet onder geregeld bestuur zijn gebracht, zijn in den bovenloop Pangkalan-Indawong, Pangkalan-Sari en PangkalanKapas, terwijl ten Oosten van dit laatste zich de VIII Kota uit-

o. c., blz. 18 , noot.

4 Gloegoer III Kota di-moediq bestond, gelijk uit den naam blijkt, oorspronkelijk uit eene federatie van drie kota's; nu omvat het er echter zes. Naar de voornaamste kota, Moewara of Moewara-Soengei-Lolo, gelegen aan de uitwatering van de Soengei-Lolo in de Kampar, heet het landschap Gloegoer III Kota dimoediq ook Moewara-Soengei-Lolo VI Kota.

Kampar nan XII Kota is onderscheiden in twee deelen, namelijk Kampar toengkoe nan III, oorspronkelijk bestaande uit drie, later uit zes dorpen, en Kampar nan VII Kota, uit zeven dorpen samengesteld, waarvan echter later een verdween.

6 En wel Pangkalan-Kota-Baroe en de XII Kota Kampar in Januari 1879, Gloegoer III Kota di-ilir in Juni 1881, en Gloegoer III Kota di-moediq of MoewaraSoengei-Lolo VI Kota in Mei 1882. De drie eerstgenoemde landschappen zijn administratief gebracht tot de afdeeling L Kota van de Padangsche Bovenlanden, terwijl Gloegoer III Kota di-moediq of Moewara-Soungei-Lolo VI Kota gevoegd is aan de afdeeling Ajer-Bangis en Rau van de Padangsche Benedenlanden. 
strekken, eene federatie van acht dorpen, waarvan Seilan het voornaamste is. Even vóór de vereeniging van de Kampar-Kanan en de Kampar-Kiri begint het gebied van het rijk Poelau-Lawan of Pelalawan, dat zich verder langs de beide oevers der KamparBĕsar tot aan de straat van Malaka uitstrekt, welk rijk, nadat de vorst de suzereiniteit van Nederland erkend heeft, in 1882 bij het Gouvernementsgebied is ingelijfd $\mathbf{7}$.

Gaan wij nu na in hoeverre in het stroomgebied der Kampar het matriarchaat gevonden wordt. - Dit is vooreerst het geval in Gloegoer VI Kota, XII Kota Kampar en Pangkalan-Kota-Baroe. Van het eerstgenoemde landschap lezen wij: "De maatschappelijke instellingen wijken van de zuiver Maleische (dat is dan: Menangkabausch-Maleische) niet af. Het volk is verdeeld in suku's, welke naar het aantal familiehoofden wederom in buwah-pĕrut of rumah zijn onderverdeeld ..... Bij erfopvolging houdt men zich vast aan de adat-kamanakan", met andere woorden aan de bepaling dat de kamanakan's of zusterskinderen de nalatenschap bekomen $\mathbf{3}$. Ook in de XII Kota Kampar "wordt de adat-kamanakan nog zonder afwijkingen toegepast. Suku-verdeeling, huwelijk, in het kort alle instellingen zijn hier geheel (Menangkabausch-) Maleisch" 9. Uitvoeriger zijn de mededeelingen omtrent Pangkalan-Kota-Baroe. Men treft hier nog de indeeling in suku's aan en het verbod om in de suku te trouwen. Uitzonderingen op dezen regel komen echter voor in een paar dorpen, waar leden van dezelfde suku wel een huwelijk met elkander mogen aangaan, mits de betrokkenen niet onder denzelfden panghulu staan, dat is, met andere woorden, niet tot dezelfde familie behooren. De vrouw blijft na hare echtvereeniging bij hare ouders wonen, terwijl de kinderen hare suku volgen. Wat echter het erfrecht betreft, wordt de regel dat van den man alleen de kamanakan's erven, niet meer zoo streng toegepast; integendeel hebben de eigen kinderen ongeveer gelijke rechten als de zusterskinderen op de nagelaten bezittingen. Titels en waardigheden gaan echter nog uitsluitend in de vrouwelijke lijn over 10. - Van de

\footnotetext{
7 Administratief is Poelau-Lawan gebracht tot de residentie Sumatra's Oostkust.

${ }^{8}$ Van Delden, Verslag over den toestand van het landschap Gloegoer VI Kota, Tijdsehr. v. Ind. T. L. en Vk., dl. XXVII, blz. 169.

${ }^{9} \mathrm{Du}$ Ry van Beest Holle, Aanteekeningen betreffende de landschappen VI Kota Pangkalan ( = Pangkalan-Kota-Baroe) en XII Kota Kampar, Tijdschrift v. Ind. T. L. en Vk., dl. XXIV, blz. 386 .

${ }^{10} \mathrm{Du}$ Ry van Beest Holle, O. c., blz. $380-381$. 5e Volgr. III. 
overige deelen van het stroomgebied der Kampar ontbreken ons directe mededeelingen betreffende de inrichting van de verwantschap en het huwelijks- en erfrecht. Dat echter in de V Kota Kampar het matriarchaat voorkomt, is zeer waarschijnlijk. Dit landschap toch wordt gezegd dezelfde bevolking te hebben als de XII Kota Kampar: beide streken waren dan ook slechts kabung's of onderdeelen van een grooter geheel $\boldsymbol{} \boldsymbol{1}$. Zoo is verder uit hetgeen van de bewoners van de landschappen der Kampar-Kiri gezegd wordt, dat zij namelijk "verwant zijn aan de bevolking van de landschappen der KamparKanan en gelijke zeden en gebruiken hebben als die der Padangsche Bovenlanden" 12, op te maken, dat ook zij het matriarchaat hebben. Wat echter Poelau-Lawan betreft, is het onwaarschijnlijk dat hier de instelling nog gevonden wordt. Onder den invloed van Djohor moet zij integendeel in dit gebied, evenals in de andere kustlanden, gelijk straks zal blijken, verloren gegaan zijn. Wij vinden dan ook nergens iets vermeld, dat aan het bestaan van het matriarchaat hier denken doet, behalve de mededeeling dat bij echtscheiding al de kinderen de moeder volgen ${ }^{13}$.

Noordelijk van de Kampar stroomt de Siak, die uit de vereeniging ontstaat van twee rivieren de Tapoeng-Kiri en de Tapoeng-Kanan, en tot voornaamste zijtakken heeft rechts de Gasip en links de Mandau. Het benedenstroomgebied wordt ingenomen door het rijk van Siak. Voorheen behoorde, gelijk bekend is, dit gebied aan den sultan van Djohor. Het gezag van dezen vorst strekte zich uit tot Pasir-Sala, ongeveer een uur roeiens boven het tegenwoordige Pakan-Baroe gelegen 14. Rechtstreekschen invloed schijnt echter

${ }^{11}$ Het woord kabung beteekent "een gedeelte van een geheel", bij voorbeeld een gedeelte van een stuk lijnwaad. Zoo spreekt men dus ook van kabung-ajer, dat is "een gedeelte van het stroomgebied eener rivier". Elk der beide deelen, waaruit, gelijk wij boven in noot 5 gezien hebben, de XII Kota Kampar oorspronkelijk bestond, was een kabung, terwijl de derde kabung door de V Kota Kampar gevormd werd (Zie: Aanteekeningen omtrent Midden-Sumatra uit officiëele bescheiden ontleend, Verhandelingen v. h. Bat. Gen. v. K. en W., dl. XXXIX, blz. 20). Samen maakten dus de XII Kota Kampar en de V Kota Kampar eene groote federatie uit. In 1859 zijn echter de betrekkingen tusschen die twee deelen afgebroken (Tijdschr. v. Nederl. Indië, jaarg. 1880, dl. I, blz. 169).

12 Tijdsehr. v. Nederl. Indië, jaarg. 1880, dl. I, blz. 168. Zie ook : Aanteekeningen omtrent Midden-Sumatra uit officiëele bescheiden ontleend, blz. 45 .

13 Faes, Het rijk Pelalawan, Tijdschr. v. Ind. T. L. en Vk., dl. XXVII, blz. 499.

14 Dat het gezag van Djohor zich zoover uitstrekte, blijkt onder anderen uit een contract den 3 April 1685 tusschen Djohor en de Oost-Indische Compagnie gesloten. Zie: Netscher, De Nederlanders in Djohor en Siak, Bijlage IV. 
Djohor alleen uitgeoefend te hebben tot aan de Koewala-Mandau, de plaats dus waar de Mandau in de Siak valt. Men weet hoe deze landstreek in 1717 door Radja Ketjil, een avonturier vermoedelijk van Menangkabauschen oorsprong, op Djohor werd veroverd, welke Radja Ketjil de stichter werd van het tegenwoordige rijk van Siak. Het gebied van dit rijk langs de Siak-rivier is hetgeen men "Eigenlijk Siak" pleegt te noemen, in tegenstelling van de onderhoorigheden, waartoe bepaaldelijk de meer Noordelijk langs de Rokan gelegen landschappen Tanah-Poetih, Koeboe en Bangka behooren ${ }^{14^{a}}$. Van de monding der rivier strekt zich Eigenlijk Siak stroomopwaarts uit tot aan de grens der districten langs de TapoengKiri en de Tapoeng-Kanan 14b. Gewoonlijk worden deze districten ook als onderhoorigheden van Siak beschouwd. Feitelijk maken zij echter twee op zichzelf staande bondgenootschappen uit. Wel erkennen de Tapoengsche hoofden den sultan van Siak als hun souverein, doch de band, welke hen aan dezen bindt, is meer van federatieven dan van ondergeschikten aard $\mathbf{1 5}$.

In de Tapoengsche landschappen, om hiermede te beginnen, schijnt het matriarchaat nog volledig te bestaan. Dit wordt wel nergens uitdrukkelijk gezegd, doch kan uit verschillende gegevens worden opgemakt. Zoo wordt, wat deze instelling zoozeer kenmerkt, het gebruik dat bij het huwelijk de man de vrouw volgt, bij haar komt inwonen ook hier aangetroffen, hetgeen duidelijk uit de mededeeling blijkt, dat "eene geheele familie met aangetrouwde zoons zooveel mogelijk

14a Zie over deze landschappen beneden blz. 176.

14b De grens van Eigenlijk Siak met de Tapoengsche districten ligt een weinig boven het vereenigingspunt van de Tapoeng-Kiri en de Tapoeng-Kanan.

15 Hijmans van Anrooy, Siak Sri Indrapoera, Tijdschr. v. Ind. T. L. en Vk., dl. XXX, blz. 286-287 en 354 vv. - Dat de band, die de Tapoengsche landschappen aan Siak bindt, meer van federatieven dan van ondergeschikten aard is, blijkt, gelijk de heer Hijmans van Anrooy opmerkt, uit het feit dat zij ook in eene soortgelijke positie ten opzichte van Kota-Intan, een Noordelijker aan de Rokan gelegen rijkje, verkeerden. De formule, waardoor de verhouding der districten aan de Tapoeng-Kiri en de Tapoeng-Kanan tot Siak en Kota-Intan werd aangegeven, luidde: "beradja ka-Siak, bertuwan ka-Kota-Intan". Eerst in 1876 werd dit veranderd, deed Kota-Intan formeel afstand van alle rechten, die het op de beide Tapoeng's had, en liet de sultan van Siak bij plakaat aan de bevolking daar bekend maken, dat zij voortaan "beradja dan bertuwan ka-Siak" (Hijmans van Anrooy, t. a. p., en blz. 367 vlg. Zie ook : Aanteekeningen omtrent Midden-Sumatra uit officiëele bescheiden ontleend, blz. 21 en 76, en Hijmans van Anrooy, De grenzen van de Residentie Sumatra's Oostkust, en van haar samenstellende deelen, Tijdschr. v. h. Nederl. Aardrijksk. Gen., 2e serie, dl. I, blz. 305). 
in één huis geherbergd wordt, en daarvoor in de achterste ruwang (het achterste vak) verschillende gedeelten afgezonderd worden" $\mathbf{1 6}$. Verder wijst wat wij over het erfrecht vermeld vinden, hoe weinig ook, op de matriarchale inrichting der familie. Tot de voornaamste individueele bezittingen van de bewoners dezer landschappen behooren namelijk de sijalang's, boomen waarin bijen zich genesteld hebben en waarvan dus was en honig worden ingezameld. Deze sijalang's nu gaan bij overlijden van den eigenaar over op de kamanakan's, de zusterskinderen ${ }^{17}$. Niet onwaarschijnlijk is het, dat deze regel ook ten aanzien van de overige goederen geldt. Daaruit zou het dan ook alleen te verklaren zijn, dat zaken, die tot de harta-pusaka behooren, erfstukken dus zijn, bewaard worden bij de oudste zuster, zooals onder anderen van de kaběsaran, de waardigheidsteekenen, die in het bezit van enkele hoofden zijn, uitdrukkelijk gezegd wordt ${ }^{18}$. Ook de successie in ambten en bedieningen geschiedt in de vrouwelijke lijn, wordt de oom door den zusterszoon in zijne betrekking opgevolgd ${ }^{1}$. Omtrent het voorkomen van het matriarchaat in de Tapoengsche landschappen kan dus geen twijfel bestaan. In hoeverre hiermede de exogamie gepaard gaat, blijkt niet. Wel wordt de indeeling van het volk in suku's opgegeven ${ }^{20}$, doch nergens gezegd dat het huwelijk in de suku. verboden is.

Wij komen nu aan Eigenlijk Siak. Het is echter noodig, alvorens het bestaan van het matriarchaat hier na te gaan, eerst kortelijk een overzicht te geven van de bevolking van dit gebied.

In Eigenlijk Siak hebben wij eene oorspronkelijke, eene inheemsche Maleische bevolking te onderscheiden van eene in lateren tijd geimmigreerde Menangkabausche. Reeds vroeg, tijdens Siak nog onder de suprematie van Djohor stond, hadden zich vele Menangkabauërs aldaar gevestigd. Het was vooral door hunnen steun dat Radja Ketjil zich van deze landstreek heeft kunnen meester maken. Niet dus door Radja Ketjil alleen werd het rijk van Siak gevestigd, doch door hem en zijne Menangkabausche medestanders. De hoofden

16 Van Rijn van Alkemade, Verslag eener reis van Siak naar Paja-Kombo, Tijdschr. v. h. Nederl. Aardr. Gen., 2e serie, dl. II, le stuk, blz. 211.

17 Hijmans van Anrooy, Siak Sri Indrapoera, Tijdschr. v. Ind. T. L. en Vk., dl. XXX, blz. $362,364-365$ en 366 .

18 Van Rijn van Alkemade, Het rijk Gasip, Tijdschr. v. h. Nederl. Aardr. Gen., 2 e serie, dl. II, 2 e stuk, blz. 222 , noot 2 .

19 Hijmans van Anrooy, Siak Sri Indrapoera, blz. 359, 363 en 364; Van Rijn van Alkemade, Verslag eener reis van Siak naar Paja-Kombo, blz. 212-213.

20 Hijmans van Anrooy, Siak Sri Indrapoera, blz. 359, 361, 362, enz. 
van deze laatsten werden dan ook geacht met den vorst de vorstelijke waardigheid te vertegenwoordigen. Was de vorst de personificatie van de karadjaan, het rijk, zij waren de tijang-karadjaan, de stijlen waarop het rijksgebouw rust. Buiten de karadjaan zijn zij niets, maar omgekeerd kan ook het rijk niet zonder hen blijven bestaan. Tot den huidigen dag is deze toestand behouden gebleven: de Menangkabauërs worden niet als directe onderdanen van den sultan beschouwd, doch staan onder hunne eigen hoofden, datuq's, die hunne oorspronkelijke onafhankelijke positie vrij wel weten te bewaren 21. Naar de streken vanwaar zij herkomstig zijn, of liever hunne voorouders herkomstig waren, zijn deze Menangkabausche kolonisten in vier suku's verdeeld, namelijk Limapuluh, TanahDatar, Pasisir en Kampar. Die tot de suku's Limapuluh en TanahDatar behooren, zijn nakomelingen van emigranten uit de landschappen L Kota en Tanah-Datar in de Padangsche Bovenlanden, terwijl de suku's Pasisir en Kampar personen omvatten, wier voorvaderen respectievelijk uit Agam, met het Westelijk daarvan gelegen land tot aan de zee, en uit de bovenstreken van de Kampar, alsook van de Indragiri en Djambi, gekomen zijn ${ }^{22}$. Collectief worden deze kolonisten van Menangkabauschen oorsprong samengevat onder den naam Anaq IV Suku. Zij wonen door het geheele rijk verspreid, hoewel de meesten in de hoofdplaats Siak gevestigd zijn 23. - Naast de Anaq IV Suku, heeft men de oorspronkelijke bevolking, de directe onderdanen van den vorst. Zij worden onderscheiden in twee categorieën, de Hamba-Radja en de Rajat-Radja ${ }^{24}$,

${ }^{21}$ Hijmans van Anrooy, Siak Sri Indrapoera, blz. 273-274 on 311-312.

${ }^{29}$ Hijmans van Anrooy, O. c., blz. 314-315.

${ }^{23}$ Hijmans van Anrooy, O. c., blz. 317. - De Menangkabausohe kolonisten zijn niet alleen afstammelingen van hen, die, tijdens de verovering van Siak door Radja Ketjil, reeds daar woonden, doch ook van personen, welke zich er later gevestigd hebben. Voornamelijk zijn tijdens de Padri-onlusten velen uit de Padangsche Bovenlanden naar Siak uitgeweken. Zij werden natuurlijk naar de streken, vanwaar zij herkomstig waren, in eene der vier suku's opgenomen, met voorbijgang van hunne eigenlijke suku, waartoe zij door geboorte behoorden. Het woord suku heeft dus in Siak eene andere beteekenis dan in de Padangsehe Bovenlanden: de suku duidt hier geen familieverband aan, omvat niet personen van dezelfde afstamming, doch van dezelfde luwak of streek.

${ }^{24}$ Samen heeten zij orang-kabanjakan = menschen van de menigte, dat is dus : het gros, de volksklasse, in tegenstelling van de anaq-radja, de afstammelingen der verschillende vorsten, welke gezamenlijk den adel uitmaken en ter hoofdplaats Siak wonen. Men heeft dus bij de bevolking van Eigenlijk Siak de volgende bestanddeelen te onderscheiden: $1^{0}$ de anaq-radja, $2^{0}$ de anaq IV suku, $3^{0}$ de hambaradja en $\mathbf{4}^{0}$ de rajat-radja. 
welke afzonderlijk wonen, de eersten dichter bij de kust, langs den benedenloop der Siak, de anderen meer in de binnenlanden. Het schijnt dat bepaaldelijk de godsdienst als het criterium moet worden beschouwd van de onderscheiding tusschen de Rajat-Radja en de Hamba-Radja : dezen zijn namelijk goede Mohammedanen, terwijl genen in naam slechts den Islâm belijden of nog Heidenen zijn, waarom zij dan ook, als men in Siak van "Orang-Malaju" spreekt, daaronder niet worden begrepen ${ }^{25}$. Het gebied van de Hamba-Radja strekt zich uit van de monding der Siak tot aan de Koewala-Mandau, en

25 Hijmans van Anrooy, O. c., blz. 324. - Uit het feit dat de Rajat-Radja geen "Orang-Malaju" heeten, blijkt onzes inziens voldoende, dat de godsdienst het voornaamste criterium is van de onderscheiding tusschen hen en de HambaRadja. De benaming "Orang-Malaju" is, gelijk Dr. Van der Tuuk dit voorlang al heeft opgemerkt (Bijdragen tot de T. L. en Vk. v. Nederl. Indië, nieuwe volgreeks, dl. I, blz. 173, noot), op Sumatra geheel synoniem met Mohammedaan. De splitsing tusschen Hamba-Radja en Rajat-Radja dagteekent zeker van den tijd, toen de Islâm nog niet in de binnenlanden van Sumatra, en dus ook in die van Siak, drovgeadrongers mas, tijidans Djishor do swpromotio hod orow dot lomd. Do bo woners van den benedenloop der Siak, die al Mohammedanen waren, werden dus vanzelf door de Djohoreezen onderscheiden van die, welke meer bovenstrooms woonden en het Heidendom nog beleden. Bovendien moeten de eerstgenoemden zich al spoedig met de vreemde overheerschers, die in hun midden gevestigd waren, vermengd hebben, en heeft deze omstandigheid zeker in geen geringe mate or toe bijgedragen, de door den godsdienst gevormde onderscheiding soherper te maken. Op die wijze zal wel de splitsing tusschen de Hamba-Radja en de Rajat-Radja ontstaan zijn. - Wat de namen betreft, hebben hamba-radja zoowel als rajat-radja de beteekenis van "vorstelijke onderdanen" of "vorstelijke onderhoorigen", hoewel de eerste een meer intieme, een meer nauwe betrekking te kennen geeft dan de laatste. Opmerking verdient het nog dat ook op Malaka het woord rajat gebruikt wordt door de Mohammedanen der kust, ter aanduiding van de Heidensche bevolking der binnenlanden, de zoogenaamde Orang-Běnuwa. - De afscheiding tusschen de Rajat-Radja en de Hamba-Radja was vroeger zeer groot, zoodanig zelfs dat volgens de adat de eerstgenoemden niet met de laatsten samen mochten eten en huwelijken wederkeerig niet konden plaats hebben. $\mathrm{Nu}$ wordt echter hieraan minder streng de hand gehouden (Hijmans van Anrooy, O. c., blz. 324-325). - De rechten en verplichtingen van deze beide klassen van onderdanen wijken echter nog steeds van elkander af. Over het algemeen verkeeren de Rajat-Radja in ongunstiger omstandigheden. Hunne positie, zegt de Heer Hijmans van Anrooy, is over het algemeen niet benijdenswaardig. Hebben de Hamba-Radja nog eenige rechten, die de sultan te respecteeren heeft, alles wat hij zijnen Rajat's laat behouden, wordt geacht een medelijdend gunstbetoon te zijn. Zij zijn, wat men vroeger in Europa noemde, "taillable et corvéable à merci" (Hijmans van Anrooy, O. c., blz. 336-337). Tegenwoordig zijn de meeste Rajat-Radja al tot den Islâm overgegaan, althans in naam. Alleen de Orang-Sakei met de Orang-Akit, de Orang-Utan en de OrangRawa, die later ter sprake zullen komen, zijn nog Heidenen. Zie noot 27, 31 en 94 beneden, en blz. $174-175$ van den tekst. 
van beide oevers landwaarts in zoover als men het geluid der tětawaq (eene soort van gong of muziekbekken) hooren kan, sapěnděngaran pěmukul tětawaq, gelijk dit heet ${ }^{26}$. Boven de plaats waar de Mandau in de Siak valt, tot aan de grens der Tapoengsche landschappen, zijn, eveneens zoover landwaarts in als het geluid der tětawaq reikt, de Rajat-Radja gevestigd 27 . Bovendien behooren tot de Rajat-Radja de zoogenaamde Orang-Talang, onder welken naam worden begrepen al degenen, die niet langs de hoofdrivier, doch in het bosch aan of bij de zijrivieren wonen, en daar in zekeren zin een nomadisch leven leiden 23. Deze Orang-Talang worden onderseheiden in drie hoofdgroepen. T'wee daarvan komen op den rechteroever der Siak voor. Waar op dezen oever het geluid der tětawaq niet meer gehoord wordt, begint het gebied der OrangTalang, de Pertalangan gelijk het gewoonlijk genoemd wordt ${ }^{29}$. Het Westelijk gedeelte van dit gebied wordt geoccupeerd door de

26 Hijmans van Anrooy, O. c., blz. 288. - De Hamba-Radja staan onder het gezag van vier panghulu's, namelijk dien van Siak-Ketjil, van Rempah, van Siak-Běsar en van Betoeng, ieder met een eigen gebied. Over deze panghulu's zijn verder twee ambtenaren aangesteld, de bintara-kiri en de bintara-kanan. Bevelen van den sultan worden door deze bintara's overgebracht, die ook voor de richtige uitvoering daarvan zorg dragen (Hijmans van Anrooy, O c., blz. 288-290 en 325-326).

27 Deze Rajat-Radja staan onder het gezag van vier batin's, dien van Gasip, van Senapalan, van Prawang en van Si-Galas. Langs den linkeroever der Siak, te beginnen met de Koewala-Mandau, heeft men achtereenvolgens het gebied van de batin's van Prawang en van Senapalan, langs den rechteroever dat van de batin's van Gasip en van Senapalan, terwijl het gebied van den batin van Si-Galas zich van het vereenigingspunt van de Tapoeng-Kiri en de Tapoeng-Kanan stroomopwaarts langs de oevers van deze beide armen uitstrekt tot aan de grens der Tapoengsche landschappen (Hijmans van Anrooy, O. c., blz. 291-294. Zie ook: Van Rijn van Alkemade, Reis van Siak naar Paja-Kombo, Tijdschr. v. h. Nederl. Aardr. Genootsch., 2e serie, dl. II, le stuk, blz. 204, en de daarbij behoorende kaart, waarop het gebied van elk der batin's duidelijk aangegeven is, hoevel eenigszins anders dan bij den Heer Hijmans van Anrooy, waarover het slot van noot 31 hier beneden te vergelijken is). - De Rajat-Radja van de batin's van Gasip, Senapalan en Si-Galas zijn Mohammedanen, die van den batin van Prawang Heidenen, en wel volgens sommigen (Hijmans van Anrooy, O. c., blz. 292 en 351) Orang-Akit, volgens anderen (Van Rijn van Alkemade, Het rijk Gasip, Tijdschr. v. h. Nederl. Aardr. Genootsch., 2e serie, dl. II, 2e stuk, blz. 221, noot 3) Orang-Sakei.

28 Het woord talang beteekent "bosch", orang-talang dus "boschbewoner". De naam heeft derhalve volstrekt geene ethnographische beteekenis.

29 Met het Zuidelijk gelegen rijk Poelau-Lawan heeft de Pĕrtalangan geene afgebakende grenzen. Oostelijk strekt de Pěrtalangan zich uit tot aan de Mempoera, die zich, niet ver boven de hoofdplaats Siak, in de rivier van dien naam stort, en Westelijk tot aan de Tiga-Loewak of Tiga-Loerah, zooals de landstreek heet tusschen Pakan-Baroe aan de Siak en Taratak-Boeloeh aan de Kampar. 
Orang-Talang-Gasip, zoo genoemd naar de Gasip, een rechtertak van de Siak, gelijk boven reeds werd opgemerkt, het Oostelijk deel door de Orang-Talang-Dajun, welke hunnen naam ontleenen aan de Dajoen, die zich in de rivier van Poelau-Lawan stort ${ }^{30}$. De derde hoofdgroep van de Orang-Talang is gevestigd op den linkeroever der Siak, langs den benedenloop der Mandau, waarnaar deze groep ook den naam van Orang-Talang-Mandau draagt ${ }^{31}$.

In het algemeen kan het gezegd worden, dat in het gebied van den sultan van Siak, dat is dan in Eigenlijk Siak, het matriarchaat wordt aangetroffen van de grens der Tapoengsche landschappen tot aan de Koewala-Mandau, bij de Rajat-Radja dus, terwijl het beneden de Koewala-Mandau, bij de Hamba-Radja, gemist wordt. Niet onwaarschijnlijk is het, dat de instelling ook hier voorheen gegolden heeft, en eerst tijdens Djohor het gezag over Siak had, verloren is gegaan. Dat zij boven de Koewala-Mandau in stand is gebleven, is dan daaruit te verklaren, dat de rechtstreeksche invloed van Djohor, gelijk boven werd opgemerkt, zich niet verder dan tot de genoemde plaats heeft uitgestrekt ${ }^{32}$. Ook bij de Menangkabausche kolonisten, de Anaq IV Suku, wordt het matriarchaat niet ge-

30 De Poelau-Lawan is een linkertak van de Kampar.

31 Zie voor het voorgaande: Hijmans van Anrooy, Siak Sri Indrapoera, blz. 290-291 en 294-297; Van Rijn van Alkemade, Reis van Siak naar Poelau-Lawan, Tijdschr. v. h. Nederl. Aardr. Gen., 2e serie, dl. III, blz. 133-134. - Er zijn nog andere groepen van Orang-Talang, als de Orang-Talang-Pandan, de OrangTalang-Kutip enz., die echter, volgens den Heer Van Rijn van Alkemade (0. c., blz. 133), allen onder de Orang-Talang-Gasip kunnen worden begrepen. - Het hoofd van de Orang-Talang-Dajun voert den titel van patih, dat van de Orang-TalangMandau dien van panghulu, terwijl over de Orang-Talang-Gasip de, in noot 27 genoemde, batin van Gasip staat. Overigens is over de Orang-Talang-Dajun en de Orang-Talang-Gasip de bintara-kanan, en over de Orang-Talang-Mandau de bintarakiri (zie noot 26) aangesteld. Bevelen van den sultan worden door hen aan de evengenoemde volkshoofden overgebracht (Van Rijn van Alkemade, O. c., blz. 134). De godsdienst der Orang-Talang is de Islâm, die echter slechts in naam beleden wordt en waaraan men zich weinig gelegen laat liggen (Hijmans van Anrooy, O. c., blz. 295; Van Rijn van Alkemade, O. c., blz. 141). - Gelijk in den tekst is gezegd, wonen de Orang-Talang-Mandau langs den benedenloop der Mandau. Dit is volgens de mededeeling van den Heer Hijmans van Anrooy. De Heer Van Rijn van Alkemade zegt echter (vergelijk zijne in noot 27 geciteerde verhandeling, blz. 204, en de daarbij behoorende kaart), dat ook een gedeelte van het land langs den linkeroever der Siak, bij de Koewala-Mandau gelegen, an den panghulu van de Orang-Talang-Mandau behoort. Volgens deze voorstelling begint dus het gebied van den batin van Prawang niet, gelijk de Heer Hijmans van Anrooy beweert (zie noot 27), bij evengenoemde plaats, doch een weinig meer stroomopwaarts.

32 Hijmans van Anrooy, O. c., blz. 261 en 263. 
vonden ${ }^{33}$. Bij hunne vestiging in Siak hebben de Menangkabauërs dus hunne oude adat prijs gegeven. Het kan zijn, dat dit eveneens onder Djohorschen invloed geschied is; doch de zaak laat zich ook op eene andere wijze verklaren. Emigraties toch kunnen, waar zij op kleine schaal plaats hebben, het patriarchaat ten gevolge hebben. Duidelijk zien wij dit bij de Noord-Amerikaansche Indianen. "At the British Association at Montreal", aldus deelt Tylor mede, "the Hon. J. W. Powell mentioned from his own observation of American tribes a visible cause of the change from female to male kinship the necessity of tribes spreading over the country for hunting. The husband thus removing his wife from the neighbourhood of her uncles and brothers in the matriarchal settlement, naturally gets her and their children into his own power, and a kind of patriarchalism with male kinship sets in" ${ }^{34}$.

Gelijk dus werd opgemerkt, komt het matriarchaat in Eigenlijk Siak voor bij de Rajat-Radja, en dit zoowel bij die, welke langs de oevers der hoofdrivier gevestigd zijn, als bij de Orang-Talang. Van de laatsten bezitten wij eenigszins uitvoerige berichten. Ziehier hetgeen de Kontroleur Van Rijn van Alkemade ons meer bepaaldelijk van de Orang-Talang-Dajun mededeelt. Zij zijn gesplitst in zeven suku's. Huwelijken worden steeds gesloten met goedvinden van de beide partijen, suka dengan suka gelijk dit heet. De vrouw blijft in hare eigen suku, waartoe ook de kinderen behooren; de man trekt dan ook bij zijne schoonouders in, in wier woning een afzonderlijk vertrek, klambu, voor de jonggehuwden wordt afgeschoten. Bij overlijden van den vader of de moeder, blijven de kinderen aan den kant der moeder; de vader heeft op hen geenerlei recht. De Orang-Talang geeft dan ook door zijn gezegde "njam djantan tida bërtêlor ", dat is: " een haan legt geen eieren ", te kennen, dat stamverwantschap uitsluitend in de gemeenschap van stammoeder is gegrond. Hiermede is het erfrecht geheel in overeenstemming. Bij overlijden van den man komen de harta-pusaka, de familiegoederen, aan de bloedverwanten van den man, en krijgen derhalve zijne vrouw en kinderen daar niets van; evenzoo erven de bloedverwanten van de vrouw hare harta-pusaka en heeft de man daarop geen recht. De harta-pentjarian of de goederen door man en vrouw in den huwelijksstaat door gemeenschappelijken arbeid verkregen, worden,

${ }^{33}$ Hijmans van Anrooy, O. c., blz. 261, 315-316 en 317 .

Academy, dl. XXVIII, blz. 67. 
bij overlijden van de vrouw, gelijkelijk verdeeld, tusschen den man en de kinderen; bij overlijden van den man, komt de eene helft aan zijne bloedverwanten, de andere aan de vrouw en de kinderen. Laat de man bij zijn overlijden schulden na, dan moeten die betaald worden door zijne familie, en kunnen zijne eigen kinderen nooit ter voldoening daarvan tot pandelingen worden gemaakt. Anders evenwel bij overlijden der vrouw : om hare schuld te voldoen, kunnen de kinderen pandelingen worden 35 . Hetgeen hier van de OrangTalang-Dajun gezegd is, geldt ook, in de hoofdzaken althans, van de overige Orang-Talang ${ }^{36}$. - Men ziet dus, hoe streng het matriarchaat bij hen gehandhaafd wordt. Zooals uit de aangehaalde woorden van den Heer Van Rijn van Alkemade zou kunnen worden opgemaakt, schijnt daarmede, althans bij de Orang-Talang-Dajun, de exogamie gepaard te gaan. Waarschijnlijk is dit ook het geval bij de Orang-Talang-Gasip. Van de Orang-Talang-Mandau aan den linkeroever der Siak echter wordt ons uitdrukkelijk medegedeeld, dat huwelijken in de suku geoorloofd zijn ${ }^{37}$. - Ook bij de opvolging in waardigheden gelden de regelen van het matriarchaat. De hoofden worden wel door den sultan benoemd, doch aangewezen door de suku-genooten van den vorigen titularis, uit diens kamanakan's, diens zusterskinderen $\mathbf{3 8}$.

Alvorens het stroomgebied der Siak te verlaten, hebben wij nog de aandacht te vestigen op een kleinen stam, die langs den bovenloop der Mandau en in de ten Noorden daarvan gelegen landstreek gevestigd is, en bekend staat onder den naam van Orang-Sakei 39. Deze Orang-Sakei zijn Maleiers, spreken althans een dialect van het Maleisch ${ }^{40}$, zijn nog Heidenen en bevinden zich misschien van alle

${ }^{35}$ Van Rijn van Alkemade, Reis van Siak naar Poelau-Lawan, Tijdschr. v. h. Nederl. Aardr. Gen., 2e serie, dl. III, blz. 140-141.

${ }^{36}$ Van Rijn van Alkemade, O. c., blz. 139 en 141, noot. Zie ook: Hijmans van Anrooy, Siak Sri Indrapoera, blz. 341.

37 Van Rijn van Alkemade, O. c., blz. 141, noot.

38 Van Rijn van Alkemade, O. c., blz. 134 en 141. Zie ook: Hijmans van Anrooy, Siak Sri Indrapoera, blz. 341.

${ }^{39}$ Het woord sakei beteekent "onderhoorige ", zoodat orang-sakei eigenlijk geen volksnaam is, geene ethnographische beteekenis heeft. Gelijk men weet, heet een der stammea van de Orang-Běnuwa van Malaka ook Orang-Sakei. Het spreekt vanzelf, dat men uit deze gelijkheid in de benamingen niet mag concludeeren, dat die stammen identiek zijn.

${ }^{40}$ Hijmans van Anrooy, Siak Sri Indrapoera, blz. 348. Zie ook: Tijdschr. v. Nederl. Indië, jaarg. 1880, dl. I, blz. 187, waar het heet, dat de taal der OrangSakei "veel overeenkomst moet hebben met het Maleisch". 
stammen op Sumatra op den laagsten trap van beschaving. Uit de bosschen, die zij bewonen en waar zij grootendeels een zwervend leven leiden, komen zij zelden of nooit te voorschijn, zoodat zij, met geringe uitzonderingen, geheel vrij gebleven zijn van alle vreemde invloeden. Gedeeltelijk staan zij onder het gezag van Siak, waar zij gerekend worden tot de Rajat-Radja te behooren, gedeeltelijk onder dat van het Noordelijker, in het stroomgebied van de Rokan, gelegen rijk van Kota-Intan. Van deze Orang-Sakei nu vinden wij vermeld, dat zij het matriarchaat hebben. Zij zijn namelijk verdeeld in suku's ${ }^{41}$. Bij het huwelijk, aldus lezen wij, volgen de kinderen de suku van de moeder. De verdeeling van de nalatenschappen heeft dan ook naar de regelen van het matriarchaat plaats, welke regelen hier in bijna alle opzichten gevolgd worden ${ }^{42}$. Ook de successie in waardigheden geschiedt in de vrouwelijke lijn : bij overlijden van een hoofd wordt hij opgevolgd door den oudsten kamanakan, den oudsten der zusterszonen ${ }^{43}$. Dat bij de Orang-Sakei de exogamie bestaat, wordt nergens uitdrukkelijk gezegd, doch zouden de geciteerde woorden "de kinderen volgen de suku van de moeder" vanzelf doen denken, dat de vader steeds van eene andere suku is.

De Noordelijkste rivier, op de Oostkust uitwaterende, waarvan het geheele stroomgebied door Maleiers ingenomen wordt, is de Rokan, ontstaande uit de vereeniging van twee armen, de RokanKanan en de Rokan-Kiri. Langs de Rokan-Kanan liggen de landschappen Tamboesei, Ramba, Kapanoean en Rantau-Binoewang; langs de Rokan-Kiri, te beginnen met den bovenloop waar de rivier nog onder de benaming Soempoer in Noordwestelijke richting stroomt, Loeboe-Sikaping met Rau, en, Oostelijk van dit laatste, Mapat-Toenggoel, dat in 1882 onder geregeld bestuur is gebracht ${ }^{44}$,

${ }^{41}$ De Orang-Sakei van Siak zijn verdeeld in vijf, die van Kota-Intan in acht suku's. Elke suku staat onder een batin. Vandaar de benamingen Batin-Lima en Batin-Selapan, waarmede collectief de hoofden der Orang-Sakei van Siak en van Kota-Intan worden aangeduid.

${ }^{42}$ Van Rijn van Alkemade, Het rijk Gasip, Tijdschr. v. h. Nederl. Aardr. Gen., 2 e serie, dl. II, 2e stuk, blz. 238.

${ }^{43}$ Van Rijn van Alkemade, O. c., blz. 236; Hijmans van Anrooy, Siak Sri Indrapoera, blz. 350 .

4 En wel in de maand Mei, tegelijk met het Zuidelijk daarvan langs de Kampar-Kanan gelegen Gloegoer III Kota di-moediq of Moewara-Soengei-Lolo VI Kota, met welk landschap het gebracht is tot de afdeeling Ajer-Bangis en Rau van de Padangsche Benedenlanden (Zie noot 6 hierboven). 
terwijl verder benedenstrooms, nadat de Soempoer zich Oostelijk gewend en den naam Rokan-Kiri aangenomen heeft, de federatie Rokan of IV Kota en Koento, omvattende de staatjes Kota-Intan en Kota-Lama, zich uitstrekken. Beneden het vereenigingspunt van de Rokan-Kanan en de Rokan-Kiri heeft men de Siaksche onderhoorigheden ${ }^{45}$ Tanah-Poetih, Koeboe en Bangka, de beide laatstgenoemden langs de monding, het eene links, het andere ten deele links, doch voor het grootste gedeelte rechts. - Alleen van MapatToenggoel, Rantau-Binoewang, Koeboe en Bangka bezitten wij min of meer uitvoerige mededeelingen over het familie- en erfrecht. Van de overige landschappen ontbreken ons alle gegevens.

In Mapat-Toenggoel wordt het matriachaat, zij het met eenige - afwijkingen, nog aangetroffen, gepaard met de exogamie. Huwelijken in de suku zijn verboden en strafbaar. De kinderen volgen de suku van de moeder en blijven ook bij echtscheidingen, welke overigens zelden voorkomen, daartoe behooren ${ }^{46}$. Bij het erfrecht vinden wij echter eene wijziging in de adat-kamanakan. Bij overlijden van den man erven namelijk zijne zusters en kamanakan's alles, behalve als er kinderen uit het huwelijk zijn, in welk geval de helft van het vermogen op de weduwe overgaat ${ }^{47}$. Het blijkt dus dat hier de eigen kinderen, zoo niet rechtstreeks, dan toch door tusschenkomst der moeder, van hunnen vader reeds erven kunnen. De successie in waardigheden schijnt echter nog uitsluitend in de zijlinie plaats te hebben, ja zelfs bij de Mohammedaansche geestelijkheid is dit het geval, wel een bewijs hoezeer de Islâm zich in dit opzicht naar de oorspronkelijke adat heeft moeten voegen ${ }^{48}$. Verder zien wij, hoe, als een uitvloeisel van de matriarchale instellingen, bij moord het wergeld van den verslagene aan diens kamanakan's wordt uitbetaald ${ }^{49}$.

Ook in Rantau-Binoewang komt het matriarchat vrij volledig voor, verbonden met de exogamie. Niemand mag in zijne suku

${ }^{45}$ Zie boven bly. 167 .

40 Neumann, Nota betreffende de onafhankelijke landschappen Mapat-Toenggoel en Moewara-Soengei-Lolo VI Kota, Tijdschr. v. Ind. T. L. en Vk., dl. XXIX, blz. $62-63$.

47 Neumann, O. c., blz. 63.

48 Neumann, O. c., blz. 62.

49 Wel te verstaan de helft van het wergeld, de andere helft komt aan de reshters toe, die het vonnis hebben uitgesproken (Neumann, O. c., blz. 59). In de Padangsehe Bovenlanden krijgen, zooals bekend is, de bloedverwanten $\frac{2}{3}$, de rechters $\frac{1}{3}$ (Zie onze verhandeling: Het strafrecht bij de volken van het Maleische ras blz. 23). 
trouwen; de man komt bij de ouders zijner vrouw inwonen en de kinderen volgen de suku der moeder ${ }^{50}$. De suku omvat dus alleen de afstammelingen in de vrouwelijke lijn. Op dezelfde wijze is natuurlijk ook de familie, als onderdeel der suku, samengesteld: eene gemeenschappelijke stammoeder vormt het uitgangs-, het middelpunt hiervan. Vandaar dan ook het woord induq = moeder (en wel lichamelijke moeder) als benaming voor de onderdeelen, de familiën dus, waarin elke suku verdeeld is $\mathbf{5 1}$. Wat het erfrecht betreft, vinden wij vermeld, dat de harta-pusaka, het erfgoed, bij het overlijden van den man aan de zusterskinderen, de kamanakan's, vervallen; de harta-pentjarian (waarmede hier blijkbaar de goederen bedoeld worden, die de beide echtgenooten staande huwelijk door gemeenschappelijken arbeid verworven hebben en die dus ook gemeenschappelijk eigendom zijn) deelt de man, bij overlijden van zijne vrouw, met de kinderen (welke natuurlijk voor het aandeel hunner moeder opkomen); sterft de man, dan erven de kinderen alles (dat wil zeggen, al hetgeen den overledene individueel toebehoort), ten minste wauneer het jongens zijn; zijn het meisjes, dan wordt de erfenis gedeeld met de zusterskinderen van den man. Als er geen kinderen zijn, vervallen de harta-pentjarian gelijkelijk aan de nabestaanden van man en vrouw. Indien de overledene schulden nalaat, gaan die over, wat den man betreft, op de zusterskinderen, wat de vrouw aangaat, op de eigen kinderen ${ }^{52}$. Wij zien dus duidelijk hoe in Rantau-Binoewang de regelen van het matriarchaat in de hoofdzaken nog van kracht zijn. Eene voorname afwijking echter is, gelijk uit het medegedeelde blijkt, dat de kinderen hier reeds de harta-pentjarian, het individueele vermogen, van hunnen vader erven kunnen, in de eerste plaats de zoons, bij ontstentenis van

${ }^{50}$ Van Rijn van Alkemade, Beschrijving eener reis van Bengkalis langs de Rokanrivier naar Rantau-Binoewang, Bijdragen tot de T. L. en Vk. v. Nederl. Indië, vierde volgreeks, dl. VIII, blz. 45 .

${ }^{51}$ Van Rijn van Alkemade, O. c., blz. 48. - Het woord induq als benaming voor familie, onderdeel eener suku, vindt men ook in de Tapoengsche landschappen (Hijmans van Anrooy, Siak Sri Indrapoera, blz. 366-367). Het blijkt echter niet, of dit hier algemeen in gebruik is. - Van induq afgeleid, heeft men verder het woord perinduan, dat is: al wat van ééne moeder is, hetwelk in het woordenboek van Von de Wall-Van der Tuuk opgegeven wordt als benaming voor familie, gezin. Waar het eehter bijzonder in gebruik is, blijkt niet.

${ }^{52}$ Van Rijn van Alkemade, O. c., blz. 45. Wij hebben hier zooveel mogelijk de eigen woorden van den schrijver geciteerd. Hetgeen tusschen haakjes geplaatst is, hebben wij echter gemeend, er duidelijkheidshalve aan to moeten toevoegen. 
zoons, de dochters, in welk geval de zusterskinderen ook een aandeel bekomen. Zonen sluiten dus hierbij dochters en zusterskinderen uit. Ook waardigheden gaan in de vrouwelijke lijn over, allereerst op de kamanakan's. Niet alleen de eigenlijke volkshoofden, de kapalasuku, worden op deze wijze opgevolgd ${ }^{53}$, doch ook de hoogere staatsambtenaren, de rijksgrooten ${ }^{\mathbf{5 4}}$. Zelfs bij de benoeming van den bandahara, den voornaamsten der rijksgrooten, den persoon die de gemachtigde is van den vorst bij diens afwezigheid, wordt de adat-kamanakan in acht genomen. De bandahara behoort namelijk, volgens den Heer Van Rijn van Alkemade, ò tot de suku Malaju òf tot de suku Ampu, met dien verstande, dat nooit tweemaal achtereen een bandahara uit dezelfde suku wordt benoemd. Behoort de bandahara, zooals de tegenwoordige, tot de suku Malaju, dan volgt diens neef, kamanakan, en tevens tongkat of helper den volgenden bandahara, die uit de suku Ampu wordt aangesteld en nu den titel van Sri Paduka Maharadja heeft, op. Diens neef krijgt dan den titel van Pakumu Radja en de tongkat uit de suku Malaju dien van Sri Paduka Maharadja, welke laatste titel dus door den aanstaanden opvolger van den in functie zijnden bandahara wordt gedragen. Is derhalve de bandahara uit de suku Malaju, dan is de Sri Paduka Maharadja uit de suku Ampu 55.

Aangaande Tanah-Poetih, Bangka en Koeboe zịjn de berichten niet zoo uitvoerig. A priori is het echter te verwachten, dat hier, meer in het bijzonder in de twee laatstgenoemde landschappen, het matriarchaat in minder zuiveren vorm moet voorkomen. Het benedenstroomgebied van de Rokan heeft toch vroeger onder de suprematie van Djohor gestaan, en onder den invloed van de Djohoreezen zal zeker veel oorspronkelijks hier verloren gegaan zijn. Dat vóór dien tijd de matriarchale instellingen volledig in de drie landschappen moeten hebben gegolden, valt niet te betwijfelen. In Tanah-Poetih vinden wij dan ook, evenals in Rantau-Binoewang, het woord induq $=$ moeder als benaming voor familie of onderdeel eener suku ${ }^{56}$, er op wijzende hoezeer hiervan de vrouw, oorspronkelijk althans, middel- of uitgangspunt is geweest. Nog heden ten dage is zij het, die de stamhoorigheid bepaalt bij het huwelijk buiten de suku. Het is namelijk niet meer verboden, in de suku te

\footnotetext{
53 Van Rijn van Alkemade, O. c., blz. 41.

54 Van Rijn van Alkemade, O. c., blz. 40.

55 Van Rijn van Alkemade, O. c., vlz. 39.

56 Hijmans van Anrooy, Siak Sri Indrapoera, blz. 382.
} 
trouwen. Huwt iemand echter in eene andere suku dan de zijne, dan volgen de kinderen, in Koeboe en Bangka zoowel als in Tanah-Poetih, de suku der moeder 57. - Omtrent het erfrecht vinden wij alleen van Tanah-Poetih vermeld, dat de nalatenschap voor het grootste gedeelte op de eigen kinderen overgaat, hoewel ook de kamanakan's iets bekomen ${ }^{57}$ a . - Ook bij de opvolging in waardigheden wordt reeds van de oude adat afgeweken. In TanahPoetih en Bangka is het de zoon die opvolgt, doch daar de betrekkingen door personen uit de suku moeten worden vervuld, alleen wanneer hij van dezelfde suku is als de vader. Is dit niet het geval, doordat de vader in eene andere suku gehuwd is, dan gaat de waardigheid op een der zusterskinderen over ${ }^{\mathbf{5}}$. In Koeboe wordt deze beperking zelfs niet meer in acht genomen, treedt de zoon in de plaats van den vader, ook al behoort hij niet tot diens suku 5 9.

Gelijk wij reeds opmerkten, ontbreken ons omtrent de overige landschappen, Rokan of de IV Kota en Koento (Kota-Intan en Kota-Lama), langs de Rokan-Kiri, en Tamboesei, Ramba en Kapanoean, lang de Rokan-Kanan, alle gegevens. Toch kan het zeker niet gewaagd zijn, aan te nemen, dat ook hier dezelfde toestanden bestaan als in Rantau-Binoewang. Wat Tamboesei betreft, kan dit zelfs met vrij groote zekerheid gezegd worden. RantauBinoewang toch is eene zeer jonge nederzetting van uit Tamboesei, geheel uit dit laatste voortgekomen. De instellingen in beide landschappen moeten dus dezelfde zijn, en de adats in het eene eene weerspiegeling van die in het andere 60 .

Ons rest nog het gebied van de Zuidelijk van de Kampar vloeiende rivieren, de Indragiri, Djambi en Moesi, te beschouwen.

In het bovenstroomgebied van de Indragiri bevinden wij ons op den klassieken grond van het matriarchaat op Sumatra. Deze rivier doorstroomt toch in haren bovenloop, onder den naam Sinamoe, met haren voornaamsten zijtak, de Ombilin, de landschappen

${ }^{57}$ Van Rijn van Alkemade, Beschrijving eener reis van Bengkalis langs de Rokanrivier naar Rantau-Binoewang, blz. 26 en 29; Hijmans van Anrooy, Siak Sri Indrapoera, blz. 383 .

${ }^{57}$ a Hijmans van Anrooy, O. c., blz. 383.

${ }^{58}$ Van Rijn van Alkemade, O. c., blz. 26-27 en 34; Hijmans van Anrooy, 0. c., blz. 383 .

${ }^{59}$ Van Rijn van Alkemade, O. c., blz. 29.

${ }^{60}$ Van Rijn van Alkemade, O. c., blz. 37. 
L Kota en Tanah-Datar. Na dit laatste verlaten te hebben, komt de Indragiri in het onafhankelijke district Loeboe-Djambi of RantauKoeantan. De bewoners hiervan worden gezegd nauw verwant te zijn aan die van de Padangsche Bovenlanden. Het matriarchaat wordt dan ook volledig bij hen gevonden ${ }^{61}$. - Oostelijk van Loeboe-Djambi strekt zich het, tot het rijk van Indragiri behoorende, landschap Tiga-Loeroeng uit, zijnde eene vereeniging van drie dorpen, waarvan Pranap, gelegen ter plaatse waar het riviertje van dien naam zich rechts in de Indragiri ontlast, het voornaamste is. Ook hier komt het matriarchaat voor, met deze afwijking echter, dat eigen kinderen en zusterskinderen in de erfopvolging gelijke rechten hebben ${ }^{62}$. - In hoeverre in het overige gedeelte van het rijk van Indragiri, dat is in het benedenstroomgebied der rivier, de instelling nu nog gevonden wordt, blijkt niet. Alleen uit berichten van Chineesche geschiedschrijvers tijdens de Ming-dynastie (1368-1643), zien wij dat dit vroeger het geval moet zijn geweest. Volgens die berichten toch bestond te Tong-ki-gi (dat is Indragiri) de regel, dat bij het huwelijk "de man de vrouw volgde en in hare familie overging" ${ }^{63}$, waaruit zou moeten voortvloeien, dat de kinderen aan de moeder behoorden.

Zooals bekend is, draagt de Zuidelijk van de Indragiri vloeiende Djambi in haren bovenloop den naam Batang-Hari. In Zuidoostelijke richting doorstroomt deze rivier eerst het Zuidelijk deel van de Padangsche Bovenlanden en vervolgens, na zich Oostelijk gewend te hebben, de zoogenaamde Batang-Hari-districten, ook Rantaudi-baroeh geheeten, bestaande uit verschillende onafhankelijke dorpsstaatjes. Zuidelijk hiervan strekken zich de evenzeer onafhankelijke Korintji-landen uit. Alleen van deze beide streken van het zoo uitgestrekte stroomgebied der Djambi bezitten wij eenige mededeelingen. Van de Batang-Hari-districten of Rantau-di-baroeh vinden wij het bestaan van het matriarchaat vermeld. Titels en waardigheden gaan over op de broeders, daarna op de zusters, en niet zelden direct op dezen. In staatsbetrekkingen is de oudste zoon der oudste zuster de rechtmatige opvolger. Wat echter de successie in bezittingen betreft, wordt hier in zooverre van de adat-kamanakan afgeweken,

${ }^{61}$ Aanteekeningen omtrent Midden-Sumatra, aan officiëele bescheiden ontleend, blz. 50 .

62 Tijdschr. v. Nederl. Indië, jaarg. 1842, dl. I, blz. 542.

6s Groeneveldt, Notes on the Malay Archipelago and Malacca compiled from Chinese sources, blz. 77. 
dat de harta-pentjarian; het zelfgewonnen goed, dat individueel eigendom is van den man, reeds op de eigen kinderen overgaat 64 . Dezelfde regel geldt ook in Korintji. De zusterskinderen, p̌̌nakan gelijk zij heeten, erven ook hier niet meer in de eerste plaats, doch alleen bij ontstentenis van eigen kinderen $\mathbf{6 5}$.

Ten slotte komen wij aan het stroomgebied der Moesi. Bij de Maleische bevolking van al de landen, tot dit stroomgebied behoorende, heeft het matriarchaat reeds geheel voor het patriarchaat plaats gemaakt. Alleen in een enkel district, namelijk Sĕmĕndo, gelegen ten Zuiden van Pasĕmah, is dit anders. Het erfrecht is hier nog geheel het matriarchale, in dien zin dat bij overlijden van de moeder de oudste dochter uitsluitende erfgename is van de vaste goederen, de woning en de rijstvelden, welke op die wijze dus steeds in de vrouwelijke lijn blijven, terwijl alleen de roerende have onder de overige kinderen verdeeld wordt. Geheel in overeenstemming hiermede is het dan ook, dat, als de oudste dochter trouwt, de man bij haar komt inwonen. Alleen bij het huwelijk van eene jongere dochter gebeurt het wel eens, dat de vrouw deu man volgt, vooral wanneer deze reeds een huis bezit of genegen is er een te bouwen. Hoezeer overigens de kinderen hier geacht worden, meer tot de moeder dan tot den vader te behooren, blijkt daaruit, dat in geval van echtscheiding zij bij de eerstgenoemde blijven 6 e.

Wanneer wij het hiervoren medegedeelde kortelijk nagaan, zien wij hoe, met uitzondering van de kustlanden, in het stroomgebied van de Djambi, Indragiri, Kampar, Siak en Rokan, voor zoover de berichten reiken, het matriarchaat nog de heerschende vorm van de verwantschap is. Het kind behoort uitsluitend aan de moeder, terwijl de vader er geen recht op heeft, niet alleen, zooals in de Padangsche Bovenlanden, volgens eene overgeleverde leer, die weinig meer begrepen wordt, doch, hier en daar althans, nog geheel op grond van de ovulistische beschouwing, welke zooal niet tot het ontstaan, dan zeker tot de ontwikkeling en instandhouding van de instelling

\footnotetext{
${ }^{64}$ Van Hasselt, Volksbeschrijving van Midden-Sumatra, blz. 250.

${ }^{65}$ Aanteekeningen omtrent Midden-Sumatra aan officiëele bescheiden ontleend, blz. 66 .

${ }^{60}$ Gramberg, Sohets der Kesam, Semendo, Makakauw en Blalauw, Tijdschr. v. Ind. T. L. en Vk., dl. XV, blz. 459; Pauw ten Cate, Rapport van de Marga Semindo Darat, Tijdschr. v. Ind. T. L. en Vk., dl. XVII, blz. 535 en 546.
} 5e Volgr. III. 
in ruime mate heeft bijgedragen $\mathbf{6 7}$, dat het aandeel van de vrouw bij de voortbrenging grooter is dan dat van den man, zoo karakteristiek door de Orang-Talang van het stroomgebied der Siak uitgedrukt in de woorden "ajam djantan tida bertělor", een haan legt geen eieren. Het sterkst geprononceerd komt het matriarchaat natuurlijk voor, waar het met de exogamie gepaard gaat, eene gemeenschappelijke stammoeder, waarvan men uitsluitend en alleen in de vrouwelijke lijn zijne afkomst kan afleiden, het uitgangs-, het middelpunt van de suku, den stam, en daarmede ook van de familie, vormt. De berichten omtrent dit punt zijn echter weinig volledig. Met meerdere of mindere zekerheid kan alleen gezegd worden, dat de exogamie gevonden wordt in Gloegoer VI Kota, XII Kota Kampar en Pangkalan-Kota-Baroe (Kampar-Kanan), hoewel in het laatstgenoemde landschap in een paar dorpen wel eens van dien regel afgeweken wordt, bij de Orang-Talang-Dajun, de Orang-Talang-Gasip en de Orang-Sakei (Siak), in Mapat-Toenggoel en Rantau-Binoewang (Rokan), terwijl van de Orang-Talang-Mandau (Siak) en de bewoners van Tanah-Poetih, Koeboe en Bangka (Rokan) uitdrukkelijk medegedeeld wordt, dat huwelijken tusschen leden van dezelfde suku, denzelfden stam, bij hen reeds toegelaten zijn. Van de overige landschappen ontbreken ons alle mededeelingen ${ }^{68}$.

Geheel in overeenstemming met het matriarchat is de regeling van het erfrecht. Afwijkingen van de adat-kamanakan, van de bepaling dat de bezittingen van den man niet op de eigen kinderen,

67 Zie hiervoor onder anderen onze verhandeling: Oostersche en Westersche rechtsbegrippen, Bijdragen tot de T. L. en Vk. v. Nederl. Indië, vijfde volgreeks, dl. III, blz. 125-126 (blz. 5-6 van den overdruk).

68 Zooals men weet, wordt ook in de Padangsche Bovenlanden het verbod, om in den stam te huwen, niet overal meer met even groote strengheid gehandhaafd. In Tanah-Datar bij voorbeeld trouwt men, volgens den Heer Stibbe (Het sukubestuur in de Padangsche Bovenlanden, Tijdschr. v. Nederl. Indië, jaarg. 1869, dl. I, blz. 32), reeds in de suku, mits, gelijk dit in Pangkalan-Kota-Baroe, blijkens het hierboven (blz. 165) medegedeelde, ook het geval is, de vrouw slechts van eene andere familie of buwah-perut is. Hiermede komt de mededeeling van den Heer Van Hasselt (Volksbeschrijving van Midden-Sumatra, blz. 282) overeen, dat van de exogamie veelvuldig in de Padangsche Bovenlanden afgeweken wordt, waar het eene echtverbintenis buiten het dorp geldt. Vanzelf behooren partijen dan toch tot twee verschillende familiön. Dat overigens het huwelijk buiten den stam nog als adat beschouwd wordt, blijkt daaruit, dat, althans in Agam, men niet in den stam mag trouwen, zonder alvorens een feest aan de ingezetenen gegeven en eene geldsom voldaan te hebben, ten einde daardoor de overtreding als het ware goed te maken (Van der Toorn, Aanteekeningen uit het familieleven bij den Maleier in de Padangsche Bovenlanden, Tijdschr. v. Ind. T. L. en Vk., dl. XXVI, blz. 518). 
doch op de zusterskinderen overgaan, komen echter ook voor. Gelijk bekend is, wordt deze adat in de Padangsche Bovenlanden nog streng gehandhaafd. De kinderen bekomen bij den dood van den vader niets en kunnen alleen tijdens diens leven geschenken van hem ontvangen. Voor zulk eene schenking mogen, gelijk vanzelf spreekt, alleen de harta-pentjarian, de particuliere bezittingen, in aanmerking komen. Doch ook hierover kan de man niet onbeperkt beschikken, maar staat hij ten dezen onder de contrôle van de aanstaande erfgenamen, die reeds bij het leven van den erflater rechten op de vermoedelijke nalatenschap kunnen doen gelden, en die er dan ook steeds op uit zijn, om elke vervreemding tegen te gaan. Toch is het langzamerhand in vele streken regel geworden, dat althans de helft van de harta-pentjarian van den man door schenking aan de eigen kinderen ten goede kan komen $\mathbf{6 9}$. Buiten de Padangsche Bovenlanden nu is men in dit opzicht hier en daar verder gegaan. In de Tiga-Loeroeng (Indragiri) hebben de eigen kinderen in de erfopvolging gelijke rechten met de zusterskinderen, gaat dus reeds bij versterf de helft der bezittingen van den vader op hen over. Dezelfde regel geldt ook in Pangkalan-KotaBaroe (Kampar-Kanan) en Mapat-Toenggoel (Rokan). In Tanah-Poetih (Rokan) wordt de nalatenschap niet alleen reeds tusschen de eigen kinderen en de zusterskinderen verdeeld, doch krijgen de eerstgenoemden zelfs het grootste gedeelte, terwijl in Rantau-di-baroeh en Korintji (Djambi) de laatste schrede in die richting al gedaan is, de zusterskinderen nog alleen in aanmerking komen bij ontstentenis

${ }^{69}$ Het komt ook wel voor, dat de man bij testament over zijne pentjarian-goederen beschikt. Eene schenking blijft echter de voorkeur verdienen, dewijl men op die wijze verzekerd is van de richtige nakoming van zijnen wil, ook na zijnen dood. Overigens moet elke schenking plaats hebben, bij roerende goederen, met medeweten, bij onroerende, met goedvinden van hen, die aanspraak op de nalatenschap hebben, en van het familiehoofd. Komt men deze voorwaarden niet na, dan is het zeker, dat bij sterfgeval het geschonkene tot in de geringste kleinigheid wordt teruggeëischt. Vooral in de afdeeling Padangsche Ommelanden kumt de schenking veelvuldig voor, en baant zij er den weg tot eene meer met onze sociale begrippen overeenstemmende regeling van het erfrecht (Zie onze verhandeling: Over de verwantschap en het huwelijks- en erfrecht bij de volken van het Maleische ras, blz. 29, en verder: Van Hasselt, Volksbeschrijving van Midden-Sumatra, blz. 247-248; Verkerk Pistorius, Studiën over de inlandsche huishouding in de Padangsche Bovenlanden, blz. 45-46; Van der Toorn, Aanteekeningen uit het familieleven bij den Maleier in de Padangsche Bovenlanden, Tijdschr. v. Ind. T. L. en Vk., dl. XXVI, blz. 515 en 526; Kroesen, Het grondbezit ter Sumatra's Westkust, Tijdschr. v. Ned. Indië, jaarg. 1874, dl. II, blz. 20 ; Résumés van het onderzoek naar het grondbezit op Sumatra, blz. 19 en 21 ). 
van eigen kinderen, dezen dus uitsluitend erven. Eenigszins bijzonder is de regel in Rantau-Binoewang (Rokan). Ook hier gaan al de harta-pentjarian, al de individueele bezittingen, van den man op de eigen kinderen over: in de eerste plaats echter erven de zoons, en alleen wanneer dezen er niet zijn, de dochters, in welk geval de zusterskinderen ook iets bekomen. Zonen sluiten dus dochters van de nalatenschap uit. De reden van deze bevoorrechting vinden wij niet vermeld, doch eene gissing hieromtrent is wel te maken. Naast de harta-pentjarian, het individueele vermogen, door eigen vlijt verworven, heeft men de harta-pusaka, het erfgoed, dat communaal bezit is. Evenals in de Padangsche Bovenlanden, en om dezelfde reden als daar $\mathbf{7 0}$, zullen misschien ook in Rantau-Binoewang voor deze erfgoederen de vrouwelijke leden der familie eerder in aanmerking komen dan de mannelijke, voor hetgeen de moeder nagelaten heeft en dat pusaka van de gezamenlijke kinderen is, de meisjes dus eerder dan de jongens. Het kan nu zijn, dat deze bevoorrechting van de dochters boven de zoons, bij de opvolging in de bezittingen der moeder, den vader er toe gebracht heeft, juist omgekeerd de laatsten boven de eersten voor te trekken, waar het de successie in zijne nalatenschap gold. - Tegenover de genoemde streken, waar reeds min of meer van de adat-kamanakan afgeweken wordt, staan echter andere, waar de oude instelling nog in alle zuiverheid wordt gehandhaafd. Zoo - om alleen de landschappen te vermelden, waarvan wij bepaalde mededeelingen hebben - in het district RantauKoeantan (Indragiri), in Gloegoer VI Kota en in de XII Kota Kampar (Kampar-Kanan), in de Tapoengsche landsshappen en in het gebied van de Orang-Talang en de Orang-Sakei (Siak).

Waar het matriarchaat bestaat, gaan niet alleen goederen, doch ook titels en waardigheden uitsluitend in de vrouwelijke lijn over. Het is dan ook bij het overlijden van een hoofd niet de eigen zoon die hem opvolgt, doch de oudste zoon van de ondste zuster. Deze regel geldt allerwege in de door ons beschouwde landschappen, zelfs daar, waar, bij de successie in bezittingen, reeds belangrijk van de adat-kamanakan afgeweken wordt ${ }^{\mathbf{7 1}}$, gelijk in Rantau-

70 Zie: Verkerk Pistorius, Studiën over de inlandsche huishouding in de $\mathrm{Pa}$ dangsche Bovenlanden, blz. 47, en onze in de voorgannde noot geciteerde verhandeling, blz. 27.

71 Ook bij andere volken zien wij, hoe bij de successie in waardigheden, bij de politieke erfopvolging dus, de afstamming in de vrouwelijke lijn in acht genomen wordt, terwijl dit bij de gewone burgerlijke niet meer plaats heeft. Zoo vernemen 
di-baroeh (Djambi), Pangkalan-Kota-Baroe (Kampar-Kanan), MapatToenggoel en Rantau-Binoewang (Rokan). Kenmerkend is het zeker, dat, gelijk in Mapat-Toenggoel, zelfs de bedieningen van Mohammedaansch geestelijke erfelijk in de zijlinie zijn, op de zusterskinderen dus overgaan. - Afwijkingen van deze wijze van successie vinden wij alleen van Tanah-Poetih vermeld. Hier gaat de waardigheid van hoofd reeds op den zoon over, zoo deze althans van dezelfde suku is als de vader. Is dit niet het geval, doordat de vader in eene andere suku getrouwd is, dan is het de zusterszoon die opvolgt 72 .

Uit het in de voorgaande regelen geresumeerde blijkt, dat in verschillende streken, naast de moederlijke rechten, de vaderlijke begonnen zijn, zich te ontwikkelen, de matriarchale verwantschap zich dus daar in den toestand van overgang tot de parentale bevindt. In de kustlanden schijnt, onder vreemden, bepaaldelijk Djohorschen, invloed, deze overgang reeds volledig tot stand gekomen te zijn ${ }^{72 a}$. Van het benedenstroomgebied der Siak, tot aan de Koewala-Mandau, hebben wij toch uitdrukkelijk vermeld gevonden, dat daar het matriarchaat niet meer voorkomt, terwijl in Bangka en in Koeboe (Rokan) van de geheele instelling blijkbaar niets meer overgebleven is dan de regel, dat, bij een huwelijk buiten de suku, de kinderen de moeder volgen ${ }^{72 b}$, en, wat het eerstgenoemde landschap betreft,

wij van Dr. Riedel (De sluik- en kroesharige rassen tusschen Selebes en Papua, blz. 315 , 320, 375 en 383), dat op enkele van de Zuidwester-eilanden, met name op de groep van Loewang-Sermata en op Leti-Moa-Lakor, priesterlijke en andere bedieningen op de zusterszonen overgaan, terwijl er in de regelen omtrent de verdeeling der nalatenschappen, gelijk wij die bij denzelfden schrijver uiteengezet vinden (0. c., blz. 330 en 395), weinig of niets te bespeuren is, dat aan het matriarchaat herinnert. Het is trouwens, gelijk Kohler dit ergens heeft opgemerkt (Zeitschrift für vergleichende Rechtswissenschaft, dl. VII, blz. 375), een veelvuldig voorkomend verschijnsel, dat "die Erbfolge in die Häuptlingsschaft stationärer und alterthümlicher ist als die Vermögenserbschaft".

${ }^{72}$ Dat deze bepaling het trouwen in de suku bevorderlijk moet zijn, spreekt vanzelf. Wij hebben hier waarschijnlijk eene der oorzaken, die ook elders tot de endogamie geleid hebben. Waar toch het matriarchat bestaat, kan bij voorbeeld de vader, evenzeer alleen door in zijn eigen stam, ja in zijne eigen familie, te trouwen, zijne kinderen doen deelen in het genot van de erfgoederen, welke communaal bezit dier familie zijn.

72a Immers de Djohoreezen-zelve moesten, toen zij begonnen, zich op de Oostelijke kustlanden van Sumatra te vestigen en met de Maleiers daar zich te vermengen, reeds volledig tot de parentale verwantschap zijn overgegaan. Zie hierover noot 76a beneden.

${ }^{72 b} \mathrm{Ook}$ in het benedenstroomgebied der Siak schijnen, bij een huwelijk buiten de suku, de kinderen de moeder te volgen (Hijmans van Anrooy, Siak Sri Indrapoera, blz. 316). Intusschen vinden wij dit slechts zoo terloops medegedeeld, dat eene nadere bevestiging hiervan zeker niet overbodig is. 
ook de bepaling, die wij reeds in Tanah-Poetih hebben aangetroffen, dat, bij de opvolging in waardigheden, de zusterszoon in aanmerking komt, als de eigen zoon van een anderen stam is dan de vader. Van Poelau-Lawan (Kampar) en het benedenstroomgebied der Indragiri bezitten wij geene bepaalde mededeelingen, doch zou het zeker niet gewaagd zijn, met het oog op den invloed, dien de Maleiers van Djohor en van den Riouw-Lingga-Archipel op de bewoners dier streken uitgeoefend hebben, te onderstellen, dat ook hier de parentale verwantschap reeds geheel in de plaats van de matriarchale getreden is, hoewel overblijfselen van de oude familieinrichting er zich nog voordoen, gelijk onder anderen de regel in het eerstgenoemde rijk, dat bij echtscheiding de kinderen bij de moeder blijven. Ook van de benedenlanden der Djambi ontbreken ons alle gegevens. Met den Heer Van Hasselt mogen wij echter wel annemen, dat bij de bewoners van dit gebied, die zich zoozeer met vreemdelingen vermengd hebben, het matriarchaat zeker niet meer wordt gevonden.

Zien wij dus hoe in de Oostelijke kustlanden de matriarchale verwantschap langzamerhand in de parentale overgegaan is, anders in het Zuiden, in het stroomgebied der Moesi. Met uitzondering van het landschap Sĕmĕndo, is overal hier het matriarchaat geheel verdwenen, doch de familieinrichting, welke daarvoor in de plaats gekomen is, is niet de ouderlijke, doch de vaderlijke, de patriarchale of agnatische. Vooral in de bovenstreken is deze familieinrichting, behoudens afwijkingen die zich hier en daar beginnen voor te doen, nog heden ten dage de heerschende ${ }^{73}$. Dat de Sĕmĕndoërs te midden van deze omgeving het oude matriarchaat, zij het ook niet meer in zijnen oorspronkelijken vorm, zijn blijven beoefenen, is zeker zeer karakteristiek, en kan een gevolg zijn van het conservatisme, dat hun in groote mate eigen moet zijn ${ }^{\mathbf{7 4}}$.

De resultaten van het in de voorgaande bladzijden ingesteld onderzoek samenvattende, komen wij tot de conclusie, die echter in vele opzichten eene nadere bevestiging verdient en dus als eene voorloopige moet worden beschouwd, dat Midden-Sumatra, wat de inrichting van de verwantschap betreft, kan worden verdeeld in: 10 de Padangsche Bovenlanden met de aangrenzende streken langs

73 Zie hierover onze verhandeling: Over de verwantschap en het huwelijks- en erfrecht bij de volken van het Maleisohe ras, blz. 55 vv. en $97 \mathrm{vv}$.

74 Gramberg, Schets der Kesam, Semendo, Makakauw en Blalauw, Tijdschr. v. Ind. T. L. en Vk., dl. XV, blz. $455-456$. 
den boven- en voor het grootste gedeelte ook den middenloop van de Moesi, Indragiri, Kampar, Siak en Rokan, waar het matriarchaat in zuiveren vorm of meer of minder gewijzigd voorkomt, 20 het stroomgebied der Moesi, waar de patriarchale, en 30 de Oostelijke kustlanden, waar de parentale familieinrichting heerscht. Min of meer valt, opdat wij dit hier nog opmerken, deze indeeling samen met de taalkundige. In het gebied van het matriarchaat toch is de taal het Menangkabausch-Maleisch, in dat van het patriarchaat een dialect, dat men het Midden-Maleisch heeft genoemd, terwijl daar, waar de parentale verwantschap bestaat, het Riouw-Linggasch resp. Djohorsch-Maleisch gesproken wordt $\mathbf{7 5}^{\text {, }}$

Van deze drie verwantschapsstelsels is het matriarchaat, gelijk wij dit in het voorgaande reeds meermalen stilzwijgend aangenomen hebben, het oudste, en moet het door de Maleiers algemeen beoefend zijn geworden, toen zij het vasteland van Azië verlieten, ow zich op Sumatra te vestigen. Men weet dat de overlevering van de zaak eene andere voorstelling heeft willen geven. Volgens het verhaal toch zou de, het matriarchaat zoozeer kenmerkende, adat-kamanakan eerst nadat de Maleiers bezit hadden genomen van de Padangsche Bovenlanden, door de twee bekende wetgevers, de gebroeders Datuq Katumĕnggungan en Perrpatih Sabatang, ingesteld zijn geworden. Toen dezen namelijk zich eens naar Atjeh wilden begeven, werd hun vaartuig op het strand geworpen, en daar het water laag was, zeiden zij tot hunne kinderen: "Komt hier om tot rollen voor onze gestrande boot te dienen". Hunne kinderen weigerden dit, maar hunne neven (zusterskinderen) boden zich bereidwillig daartoe aan. Daarom werd bepaald, dat voortaan de nalatenschap niet in de rechte lijn op de kinderen of kindskinderen, maar op de zusterskinderen zou overgaan. $W_{i j}$ mogen natuurlijk aan dit fantastische verhaal geenerlei waarde toekennen, en daaruit zelfs niet, gelijk sommigen dit hebben willen doen, de conclusie trekken, dat de adat-kamanakan op een gegeven tijdstip als iets nieuws

${ }^{75}$ Zie de door de Heeren Holle en Brandes vervaardigde taalkaart van Sumatra, behoorende bij het Koloniaal Verslag van 1887. Het dient echter te worden opgemerkt, dat, onder meer, ook in het gebied van Siak de taalgrens niet geheel samenvalt met de grens tusschen de matriarchale en de parentale verwantschapsstelsels, daar de.eerste op de kaart Westelijker getrokken is, een weinig beneden de vereeniging van de Tapoeng-Kiri en de Tapoeng-Kanan. Misschien dat een nader onderzoek zal leeren, dat dit minder juist is, en dat de Koewala-Mandau ook het punt is, waarover de taalgrens behoort te loopen. 
ingevoerd is geworden ${ }^{\mathbf{7 6}}$. Integendeel; het feit dat door stammen, die, gelijk de Orang-Talang en meer nog de Orang-Sakei, op ongeveer denzelfden trap van beschaving zijn blijven staan als waarop de Maleiers zich algemeen moeten hebben bevonden bij hunne vestiging op Sumatra, het matriarchat volledig en in den meest zuiveren vorm beoefend wordt, pleit zeker voor de oudheid en de oorspronkelijkheid dezer instelling ${ }^{76 a}$.

Als de Noordelijkste rivier, waarvan het geheele stroomgebied door Maleiers bewoond wordt, hebben wij de Rokan leeren kennen 77 . Ten Noorden van de Rokan komen wij in het land der Bataks. Dezen hebben echter alleen de binnenlanden geoccupeerd, terwijl langs de kusten de Maleiers nog verder voortgedrongen zijn, zoodat de geheele streek van den mond der Rokan tot aan Kaap Tamiang, de grens van Atjeh, door hen ingenomen wordt. Van de Maleiers, die hier gevestigd zijn, bezitten wij hoogst onvolledige berichten. Het schijnt echter dat zij het matriarchaat grootendeels, zeker onder

${ }^{76}$ Hoe weinig dit mag geschieden, blijkt nog uit eene opmerking van Dr. Van der Tuuk betreffende de namen Datuq Katumenggungan en Perpatih Sabatang, volgens welke men hier slechts met twee legendarische personen te doen heeft. Zonder moeite herkent men namelijk hier twee Javaansche ambtstitels tumenggung en patih, zoodat katumenggungan met "het tumenggungschap", en perpatih met "de patih's" te vertalen is. Daar nu, volgens Dr. Van der Tuuk, deze ambtstitels in het Menangkabausch-Maleisch niet in zwang zijn, moet men, naar den geest der Maleische overlevering, vanzelf tot de gevolgtrekking komen, dat die namen als verpersoonlijkte feiten op eene Javaansche overheersehing wijzen (Van der Tuuk, Bataksche ehrestomathie, dl. IV, blz. 123).

76a Het mag dan zeker niet gewaagd heeten, de conclusie verder uit te strekken, en bij de nauwe verwantschap, welke er tusschen de Maleiers van Sumatra en die van den Riouw-Lingga-Archipel en van Djohor bestaat, aan te nemen, dat ook deze laatsten aanvankelijk het matriarchaat hebben gehad. Dat daarvan geene overblijfselen meer bij hen aangetroffen worden (althans voor zoover onze kennis reikt), is zeker een gevolg daarvan, dat zij die instelling reeds vroeg prijs gegeven hebben, waarvoor alle aanleiding bestond in hunne veelvuldige aanrakingen met vreemdelingen, bepaaldelijk Mohammedanen. Voor de oorspronkelijke matriarchale verwantsohap is toen zeker de parentale in de plaats getreden. Onder den invloed van den Islâm toch was er geene andere oplossing mogelijk, een overgang tot de streng agnatische familieinrichting althans niet denkbaar, van welke familieinrichting dan ook bij hen geene sporen schijnen te bestaan. Zoo moesten dus de Djohoreezen reeds volledig de parentale verwantschap hebben aangenomen, toen zij begonnen, zich op de Oostelijke kustlanden te vestigen en met de Maleiers daar zich te vermengen.

77 De uitdrukking "het geheele stroomgebied" is niet geheel juist, daar toch het grootste gedeelte van de streek, waardoor de Sosah, een linkertak van de Rokan-Kanan, vloeit, door Bataks bewoond wordt. 
vreemde, bepaaldelijk Mohammedaansche, invloeden, hebben prijs gegeven. Toch ontmoeten wij hier en daar duidelijke overblijfselen van deze instelling. Zoo in Laboean-Batoe, het onmiddelijk ten Noorden van Koeboe gelegen benedenstroomgebied van de Pane en de Bila. Bij de Maleiers van dit landschap is het meest gewone huwelijk het semando. De vrouw is dan hoofd van het gezin. De man komt bij haar inwonen en treedt in hare familie. Dat de kinderen meer geacht worden tot de moeder dan tot den vader te behooren, blijkt daaruit, dat bij echtscheiding zij bij de eerstgenoemde blijven ${ }^{\mathbf{7 8}}$. Omtrent het erfrecht vinden wij echter niets vermeld, dat aan het matriarchaat herinnert. De verdeeling der nalatenschappen geschiedt, zegt de Heer Neumann, zonder eenige wettelijke regeling, hoewel men beweert daarbij de bepalingen van het Mohammedaansche recht te volgen 79. - Nog hebben wij te wijzen op eene mededeeling omtrent de Maleiers, die in het landschap Batoe-Bara, een weinig Noordelijker van Laboean-Batoe gelegen, gevestigd zijn. Zij zijn in vier suku's verdeeld, die schier geheel gescheiden van elkander wonen. Deze omstandigheid maakt dat zelden huwelijken tusschen leden van verschillende suku's gesloten worden, doch dat men bij voorkeur in zijne suku trouwt. In hoeverre het matriarchaat daarbij gevolgd wordt, blijkt niet. Heeft er echter eene verbintenis buiten de suku plaats, dan is het, gelijk wij uitdrukkelijk vermeld vinden, de vrouw die de stamhoorigheid bepaalt. De man volgt in dit geval de suku der vrouw, terwijl de kinderen tot de suku der moeder behooren ${ }^{\mathbf{8} 0}$.

Langs den boven- en den middenloop der ten Noorden van de Rokan vloeiende rivieren wonen, gelijk reeds werd opgemerkt, de Bataks; Noordelijk van dezen de Orang-Alas, en daarop de OrangGaju, terwijl de kustlanden door Atjehneezen ingenomen worden.

${ }^{78}$ Neumann, Schets der afdeeling Laboean-Batoe, Tijdschr. v. Ind. T. L. en Vk., dl. XXVI, blz. 458-459; Vigelius, Memorie van overgave van het bestuur over de afdeeling Panei en Bila, Tijdschr. v. Ind. T. L. en Vk., dl. XVII, blz. 444-445. Hetgeen de Heer Vigelius vermeldt, wijkt in een paar punten af van de mededeelingen van den Heer Neumarin. Zoo zegt hij dat het wel eens voorkomt, dat de vrouw den man volgt. Misschien is dit echter eene vergissing, en heeft de schrijver het semando-huwelijk verward met het, niet door hem genoemde, huwelijk bij belandja, waarbij werkelijk de vrouw den man volgt, terwijl bij echtscheiding de kinderen verdeeld worden, de zonen bij den vader, de dochters bij de moeder blijven. Zie hierover ook noot 96 beneden.

79 Neumann, O. c., blz. 461.

${ }^{80}$ De Scheemaker, Nota betreffende het landschap Batoebarah, Tijdschr. v. Ind. T. L. en Vk., dl. XVII, blz. 472. 


\section{Zuid-Sumatra, dat is het land ten Zuiden van het stroomgebied} der Moesi, wordt, zooals men weet, door Lampongers bevolkt. Bij geen dezer stammen treft men het matriarchaat heden ten dage aan ${ }^{\mathbf{8}}$. Duidelijke bewijzen ontmoet men echter bij de Bataks, dat zij voorheen deze instelling hebbẹn gehad $\mathbf{~} \mathbf{1}^{\mathbf{a}}$. Het is noodig hierop de aandacht te vestigen.

Van algemeene bekendheid is het, dat het nu bij de Bataks geldende verwantschapsstelsel het patriarchale of agnatische is, hier nog gepaard met de exogamie. Niemand mag in zijn stam of marga huwen; de kinderen volgen den stam van den vader: de marga is dus eene vereeniging van personen, die hunne afkomst uitsluitend in de mannelijke lijn van denzelfden stamvader afleiden. Voorheen was dit echter anders, is er een tijd geweest, dat niet de man, doch de vrouw de stamhoorigheid bepaalde, dat eene gemeenschappelijke stammoeder het middel-, het uitgangspunt der familie vormde. Dit

81 Voor zoover namelijk de berichten reiken. Van de Orang-Alas en de OrangGaju weten wij toch zoo goed als niets. Alleen omtrent de laatstgenoemden hebben wij eenige mededeelingen. Daaruit is althans op te maken, dat zij de agnatische verwantschap hebben, daar de vrouw, tegen betaling van een bruidschat, overgaat in de familie van den man (Van Langen, Bijdrage tot de kennis der Gajoe-landen, Tijdschr. v. h. Nederl. Aardrijksk. Genootsch., dl. V , blz. 37). Ook de Atjehneezen hebben dit verwantschapsstelsel, gelijk de Heer Van Langen ons mededeelt, en evenzoo, zooals van algemeene bekendheid is, de Bataks en de Lampongers.

s1a In hoeverre dit ook bij de overige volken het geval is, valt moeielijk te zeggen. Alleen van de Atjehneezen deelde ons de Heer Van Langen, die door zijn langdurig verblijf in Noord-Sumatra zeker als een bevoegd getuige mag worden beschouwd, iets mede, dat, oppervlakkig bezien, een overblijfsel van het matriarchaat schijnt te zijn. Eene vrouw namelijk in de zoogenaamde Onderhoorigheden van Atjeh, zoowel op de Oost- als op de Westkust, die met iemand trouwt, welke niet op de plaats tehuis behoort, mag den man niet volgen, doch blijft wonen waar zij is en waar zij door hare familie onderhouden wordt, terwijl ook de kinderen aan haar behooren (Zie ook: Kruyt, Atjeh en de Atjehers, blz. 193 vlg. Volgens dezen schrijver kan de man de kinderen naar verkiezing tot zich nemen of bij de moeder laten. Misschien heeft deze mededeeling echter meer uitsluitend betrekking op het landschap Edi). Deze bepaling heeft volgens den Heer Van Langen haren bijzonderen grond daarin, dat er in de Onderhoorigheden groot gebrek aan vrouwen bestaat, zoodat men, door haar te verbieden den man te volgen, voorkomen wil, dat dit gebrek nog grooter worde (Ook Kruyt, o. c., blz. 65 , spreekt over dit gebrek aan vrouwen in de Onderhoorigheden, bepaaldelijk op de Oostkust). Wat hiervan aan moge zijn, onnoodig is het zeker in deze regeling een rechtstreeksch overblijfsel van het matriarchaat te zien. Wij vinden hier toch slechts een beginsel terug, hetwelk dikwijls bij de agnatische verwantschap voorkomt, dat vreemdelingen namelijk geen connubium bezitten, dat wil zeggen geen huwelijk met manus mogen aangaan, zoodat zij ook geen recht op de kinderen hebben (Zie hierover uitvoeriger het Aanhangsel aan het slot van dit opstel, en in het bijzonder noot 18 daarvan). 
blijkt allereerst uit de benamingen voor bloedverwantschap. Dat onder het matriarchaat personen, die met elkander verwant zijn, "moedergenooten" of "afstammelingen van dezelfde stammoeder" heeten, is even natuurlijk als het eene anomalie zou zijn, wanneer onder het patriarchaat agnaten elkander zoo betitelden. Toch wordt dit bij de Bataks gedaan. In het Daïrisch dialect noemen zij, die tot dezelfde marga, denzelfden stam behooren, elkander sěnnina, letterlijk "moedergenooten" ${ }^{\mathbf{3 2}}$, in het Tobasch dialect dongan-sabutuha, dat is "metgezellen van één buik" of "buikgenooten" $\mathbf{3}$ 3, terwijl de onderdeelen, waarin de marga's gesplitst zijn, de ondermarga's dus, ter aanduiding van hun gemeenschappelijken oorsprong, gezegd worden dongan-sada-ina, dat is "van één moeder", te zijn ${ }^{\mathbf{8 4}}$. De verklaring van deze anomalie ligt voor de hand. Oude namen duiden vaak nieuwe begrippen aan; eene zaak kan veranderen, terwijl men blijft voortgaan, ze met den eenmaal bestaanden term aan te duiden. Met de evengenoemde uitdrukkingen moet het op die wijze gegaan zijn. Zij kunnen zich alleen onder het matriarchaat gevormd hebben, en zijn behouden gebleven, toen de samenstelling der familie zich later wijzigde $\mathbf{8 5}$.

\footnotetext{
${ }^{89}$ Het woord sĕnnina is eigenlijk sin-ina, gevormd uit ina $=$ moeder met het voorvoegsel si, dat steeds door een neusklank gevolgd wordt, en, aan een substantief gehecht, evenals in het Tobasch dialect $s a$, het deelgenootschap te kennen geeft in hetgeen dat substantief voorstelt. In de uitspraak nu is sin-ina drielettergrepig, dus si-ni-na. Volgens het Daïrisch klankstelsel heeft echter de lichtere lettergreep gaarne $\breve{e}$, zoo de volgende lettergrepen een verschillenden klinker hebben (Van der Tuuk, Tobasche spraakkunst, blz. 31), zoodat si-ni-na als š̆-ni-na uitgesproken wordt. Waar de toonlooze $\breve{e}$ dus voorkomt, mag zij nooit het verlies van eene lettergreep veroorzaken; integendeel de opene lettergreep, waar zij zich bevindt, wordt gesloten door den beginner der volgende dubbel te schrijven (0. c., blz. 33). Sĕnina wordt dus in schrift sĕnnina.

${ }^{83}$ Van der Tuuk, Bataksch Woordenboek, i. v. dongan.

${ }^{84}$ Neumann, Het Pane- en Bila-stroomgebied, Tijdschr. v. h. Nederl. Aardr. Genootsch., 2e serie, dl. IV, blz. 8 .

${ }^{85}$ Dat wij bij de Maleiers op Sumatra, die het matriarchaat nog hebben, in de eerste plaats termen, gelijk in den tekst bedoeld, als benamingen voor bloedverwantschap moeten aantreffen, ligt voor de hand. Zoo is dan ook werkelijk in de Padangsche Bovenlanden sabuwah-pěrut of sabuah-paruï, dat is "die van één buik zijn ", de gewone uitdrukking voor familie (Van Hasselt, Volksbeschrijving van Midden-Sumatra, blz. 245), terwijl in Rantau-Binoewang, Tanah-Poetih en, ten deele althans, in de Tapoengsche landschappen, gelijk wij boven (blz. 177 en 178) gezien hebben, daarvoor het woord $i n d u q=$ moeder in gebruik is. Ook het hiervan afgeleide perrinduan, dat is letterlijk "al wat van ééne moeder is ", hebben wij hierboven (noot 51) leeren kennen als eene in het Maleisch bestaande benaming voor familie of gezin. Elders in den Archipel komen dergelijke woorden evenzeer voor, gelijk
} 
In de tweede plaats vinden wij een bewijs voor eene oorspronkelijke verwantschap in de vrouwelijke lijn bij de Bataks in de bepalingen omtrent de indeeling bij, en de vrijstelling van de verplichte diensten ten behoeve van de hoofden. Elk ingezetene toch is verplicht zijn hoofd bij algemeene werkzaamheden hulp te verleenen, als bij het bouwen van diens woning en telken jare bij den veldarbeid gedurende eenige dagen, namelijk een paar dagen bij de ontginning van het terrein, een paar dagen bij het planten, een paar dagen tijdens het onderhoud, en een paar dagen gedurende den oogst. Verder worden onbetaalde diensten door de bevolking gepraesteerd wanneer een hoofd op reis gaat, gasten ontvangt, en bij verschillende gebeurtenissen, als huwelijken, begrafenissen, enz. ${ }^{\mathbf{8} 6}$. De regel nu is dat alleen zij, die eene vrouw hebben, tot het praesteeren dezer diensten gehouden

onder anderen bij de Makassaren pasaribattangang, gevormd van battang = buik, en beteekenende "zij die tot é́n buik behooren ", ter aanduiding van de gezamenlijke broeders en zusters, van de verwantschap in engeren zin dus (Matthes, $\mathrm{Ma}-$ kassaarsch woordenboek, i. v. saribattang). Blijkbaar is deze uitdrukking af komstig uit den tijd, toen het matriarchat ook bij dit volk bestond. Een gelijksoortigen term voor familie, die eveneens op eene oorspronkelijke afstamming in de vrouwelijke lijn terugwijst, vinden wij bij de Alfoeren van de Minahasa, namelijk sanatotoan, van toto $=$ melk, en dus letterlijk vertaald "zij die éénzelfde melk gezogen hebben". Kenmerkend is verder het woord talifusö = navelstreng als benaming voor gezin, broeders en zusters, bij de Niasers (Tijdschr. v. Ind. T. L. en Vk., dl. XXVIII, blz. 104). Het gebruik van dat woord in dien zin kan zich natuurlijk alleen gevormd hebben, toen de moeder het middel-, het uitgangspunt van de verwantschap was. Want hetgeen toen eenige personen tot bloedverwanten maakte, was de navelstreng waarmede zij aan hetzelfde moederlijf verbonden waren geweest. Zoo kan het ons dus niet verwonderen, dat ook bij de Fidjiërs het woord $v u s a$, dat aan het Maleische pusat $=$ navel beantwoordt, een term is ter aanduiding van stam of geslacht (Kern, De Fidjitaal vergeleken met hare verwanten in Indonesië en Polynesië, blz. 202) *). Vormelijk gelijk aan, en in dezelfde beteekenis gebruikt als het zooeven genoemde Maleische pĕrinduan, is het Malagasische firenena, afgeleid van reni $=$ moeder met het praefix $f$ en het achtervoegsel ina, en letterlijk beteekenende "zij die van ééne moeder zijn". - $\dot{\mathrm{D} a t}$ ook bij andere volken dan de Maleisch-Polynesische woorden voor familie in gebruik zijn, die als een overblijfsel van een oorspronkelijk matriarchaat moeten worden beschouwd, kan bekend zijn. Hier wijzen wij slechts op het Arabische fy batn = buik, $\rightarrow$ rahim $=$ uterus, verder op het Sanskritsche nabhi, dat zoowel navel als nawe bloedverwantschap beteekent.

86 Zie uitvoeriger hierover: Neumann, Het Pane- en Bila-stroomgebied, Tijdschr. v. h. Nederl. Aardr. Gen., 2e serie, dl. IV, blz. 22-23.

*) Intusschen is, gelijk Prof. Kern (t. a. p.) opmerkt, het eenigszins onzeker, dat vusa aan pusat beantwoordt. Naast vusa heeft men namelijk, in dezelfde beteekenis, yavusa. Ware nu vusa $=$ pusat, dan zou dit ya moeielijk te verklaren zijn. 
zijn. Sterft de vrouw, dan is de man vrij; sterft integendeel de man, dan blijft de vrouw, wanneer er namelijk een volwassen ongehuwde zoon in huis is, bij de verplichte diensten ingedeeld, welke zij dan, daar zij die niet persoonlijk kan praesteeren, òf moet afkoopen of door anderen tegen betaling moet laten verrichten. Het gezin houdt dus bij het overlijden van de vrouw op, dienstplichtig of, gelijk de Batak het uitdrukt, een ripe te zijn ${ }^{\mathbf{8 7}}$, terwijl het bij overlijden van den man dat blijft ${ }^{\mathbf{3}}$. Vanzelf voert ons deze regeling, die zoo geheel vreemd is aan het wezen en het karakter van de agnatische verwantschap, zoo volkomen in strijd is met het daarbij behoorende huwelijksrecht en de positie der weduwe, welke laatste wel verre van sui juris te zijn, gelijk hare dienstplichtigheid zou doen denken, integendeel niet veel meer dan als eene zaak op een der broeders van haren overleden gemaal kan overgaan ${ }^{89}$, terug tot de tijden van het matriarchaat, toen de vrouw hoofd des gezins was, de man vreemdeling in het huis zijner echtgenoote, tot het gezin zijner moeder en zuster behoorde, waarin hij echter eene ondergeschikte plaats beklẹedde. Stierf de man, dan bleef het gezin in wezen en moesten de bestaande verplichtingen vervuld worden; stierf integendeel de vrouw, dan was het gezin ontbonden en gingen die verplichtingen vanzelf dus te niet.

Een niet minder belangrijk bewijs voor een oorspronkelijk matriarchaat bij de Bataks levert ons eindelijk een eigenaardig huwelijksgebruik, dat wij bij hen aantreffen. Regel is het dat de Batak bij

${ }^{87}$ Het woord ripe beteekent "huisgezin", bepaaldelijk "dienstplichtig huisgezin", welk begrip al in de grondbeteekenis van het woord, namelijk "mede doen", opgesloten ligt (Zie: Van der Tuuk, Bataksch woordenboek, i. v. ripe).

${ }^{88}$ Neumann, Het Pane- en Bila-stroomgebied, Tijdschr. v. h. Nederl. Aardr. Gen., 2 e serie, dl. III, blz. 249 en 252 , en dl. IV, blz. 15. Zie ook onze verhandeling: Over de primitieve vormen van het huwelijk en den oorsprong van het gezin, Indische Gids, jaarg. 1881, dl. II, blz. 256-257. Deze adat-bepalingen omtrent de indeeling bij, en de vrijstelling van de verplichte diensten bij de hoofden werden, bij de invoering van de Gouvernements heeren- en kultuurdiensten, door de bevolking eenvoudig op dezen overgebracht. Tijdens ons verblijf in de Bataklanden, bepaaldelijk te Sipirok, in 1879, was de quaestie aanhangig deze diensten te hervormen, en te bepalen, dat dienstplichtig zouden zijn alle mannelijke personen, behoudens eenige vrijstellingen, van 16 tot 60 jaren. Reeds vroeger, vergissen wij ons niet, 30 jaren geleden, heeft men deze regeling willen toepassen, doch daarvan moeten terugkomen, daar volksverloop er het gevolg van dreigde te worden.

${ }^{80} \mathrm{Wij}_{\mathrm{ij}}$ hebben hier natuurlijk het leviraatshuwelijk op het oog. In de praktijk zullen de gevallen, waarin de weduwe werkelijk dienstplichtig is, door dit leviraatshuwelijk zich betrekkelijk weinig voordoen. 
voorkeur trouwt met eene dochter van zijn tulang, oom van moederszijde, moedersbroeder: boru-ni-datulang, dochter van moedersbroeder, noemt iemand dan ook zijne verloofde of vrouw, zelfs wanneer zij niet in die betrekking tot hem staat, terwijl eene vrouw haren minnaar met ibebere-ni-damang, zoon van vaderszuster, aanspreekt 90 . Het omgekeerde echter - en dit is het waarop hier bepaaldelijk de aandacht moet worden gevestigd - kan niet plaats hebben: het is een vergrijp tegen de adat, en dus ook strafbaar, eene boru-niambo, eene dochter van vaderszuster, tante van vaderskant, tot vrouw te nemen. "Is het mogelijk", vraagt de Batak, om het tegennatuurlijke van eene dergelijke verbintenis uit te drukken, "dat het water naar zijn oorsprong terugvloeit?" of gelijk het in zijne taal luidt: "marsuntjang do aek pahulu" 91. Het zonderlinge van deze bepaling springt sterker in het oog, zoo zij dus geformuleerd wordt, dat het huwelijk tusschen een zusterszoon en eene broersdochter toegelaten, tusschen een broerszoon en eene zustersdochter verboden is ${ }^{92}$. - Hoe hebben wij dit nu te verklaren? Onzes inziens door een

90 Van der Tuuk, Bataksch woordenboek, i. v. tulang, en Bataksche chrestomathie, dl. IV, blz. 49, noot, en 108; Neumann, Het Pane- en Bila-stroomgebied, Tijdschr. v. h. Nederl. Aardr. Gen., 2e serie, dl. III, blz. 243 en 492. Zie ook onze verhandeling: Plechtigheden en gebruiken bij verlovingen en huwelijken bij de volken van den Indischen Archipel, blz. 5-6.

91 Neumann, O. c., blz. 492. Zie ook onze in de voorgaande noot geciteerde verhandeling, blz. 9, en Over de primitieve vormen van het huwelijk en den oorsprong van het gezin, Indische Gids, jaarg. 1881, dl. II, blz. 255. - Als een natuurlijk uitvloeisel van het in den tekst besproken huwelijksverbod, in verband met het bij voorkeur trouwen met de dochter van een oom van moederszijde, aldus teekenden wij nog in laatstgenoemd opstel (blz. 256, noot 1) aan, zien wij hoe in de Bataklanden twee familiën, A en B bij voorbeeld, die reeds van ouder tot ouder in huwelijksrelaties met elkander staan, dit altijd in dien zin zullen zijn, dat zoo A vrouwen van B neemt, B zulks niet van A doen mag, al bestaan de betrokken personen elkander niet meer in den verboden graad van broerszoon en zustersdochter (Zie ook: Neumann, O. c., blz. 493).

92 Opmerking verdient het dat deze bepaling nog bij twee andere volken in den Indischen Archipel wordt gevonden, namelijk bij de Redjangers in de Palembangsche Bovenlanden en de Amboneezen. Van de eerstgenoemden zegt Marsden: "A sister's son may marry a brother's daughter; but a brother's son may not marry a sister's daughter" (History of Sumatra, blz. 228). Wat de Amboneezen betreft, ontmoeten wij bij hen voor "nicht" twee verschillende benamingen, namenlijk anamakain en tauli. Tegenover eene anamakain, dat is eene dochter van moedersbroeder, mag de neef zich allerlei vrijheden veroorloven; hij mag met haar lachen, gekscheren, stoeien, enz,, zonder dat dit door de ouders verboden wordt. Een huwelijk met eene anamakain is ook toegelaten en heeft dikwijls plaats. Anders echter is de verhouding tusschen een neef en zijne tauli, dochter van vaderszuster: dezen staan in nauwer betrekking tot elkander, beschouwen zich als broeder en zuster 
oorspronkelijk matriarchaat aan te nemen. Wij moeten ons dan terugdenken in den tijd, toen het patriarchaat reeds bestond, het kind al tot den vader behoorde, doch de moederlijke instellingen nog in alle opzichten hare nawerkingen deden gevoelen. Zoo kunnen wij ons voorstellen, dat terwijl de broeder toen op de zusterskinderen nog steeds, gelijk tijdens het matriarchaat, als op zijne eigen kinderen nederzag, de zuster geenszins eene dergelijke beschouwing had ten aanzien van de broerskinderen, die bij de vroegere regeling der familie vreemden voor haar, dit nu ook bleven. Bij een dergelijken stand van zaken zouden er van den kant der zusterskinderen geene bezwaren bestaan hebben tegen eene verbintenis met broerskinderen, wel echter omgekeerd. Terwijl dus zusterszonen zouden zijn voortgegaan, broersdochters tot vrouwen te nemen, resp. gewelddadig te ontvoeren - bij den overgang van het matriarchaat tot het patriarchaat, gelijk men weet, eene zeer gewone wijze om huwelijken tot stand te brengen - zouden broerszonen echter eene vereeniging met zustersdochters hebben gemeden, waaruit dan langzamerhand het begrip moet zijn voortgekomen, dat de eerste verbintenis volkomen passend, de laatste volstrekt ongeoorloofd was ${ }^{93}$.

Behalve de in de voorgaande bladzijden genoemde volken worden er op Sumatra nog eenige andere stammen aangetroffen, die hier nog vermeld dienen te worden. Zij zijn de Orang-Lubu, welke in het gebergte van Zuid-Mandäling gevestigd zijn, de Orang-Kubu, die in de wildernissen tusschen de Moesi en de Djambi rondzwerven, en de Rajat-Laut benevens de Orang-Akit, de Orang-Utan en de Orang-Rawa, die hoofdzakelijk in Eigenlijk Siak langs de kusten, zoowel op den vasten wal als op de daartegenover liggende eilanden,

\footnotetext{
en mogen niet met elkander trouwen. Het tegennatuurlijke van het aangaan eener verbintenis met de tauli drukt de Ambonees, op analoge wijze als de Batak, uit door te zeggen, dat men daardoor gelijk aan het water is, dat naar zijn oorsprong terugvloeit, of gelijk het in het locaal-Maleisch der Moluksche eilanden heet: "kaki ajer bali di kapala ajer" (Zie onze verhandeling: Plechtigheden en gebruiken bij verlovingen en huwelijken bij de volken van den Indischen Arohipel, blz. 9, en de daar aangehaalde bronnen).

${ }^{93}$ In mijne verhandeling "Over de verwantschap en het huwelijks- en erfrecht bij de volken van het Maleische ras" (blz. 37) werd door mij, als een rechtstreeksch overblijfsel van het matriarchaat bij de Bataks, nog gewezen op den bij het slavenrecht geldenden regel "partus sequitur matrem". Ondertussehen heeft een nader onderzoek mij geleerd, dat deze voorstelling minder juist is, gelijk in een aanhangsel aan het slot van dit opstel nader gal worden aangetoond.
} 
wonen, en gerekend worden tot de Rajat-Radja te behooren ${ }^{94}$, al welke stammen in meerdere of mindere mate verwant zijn met de Maleiers. Van de Orang-Akit, de Orang-Utan en de Orang-Rawa weten wij zoo goed als niets, en is het ook onbekend of zij het matriarchaat hebben. Wat de Orang-Lubu, de Orang-Kubu en de Rajat-Laut betreft, met vrij groote zekerheid kan het worden gezegd, dat die instelling bij hen niet wordt aangetroffen. Het bij laatstgenoemden bestaande verwantschapsstelsel verdient wel in het bijzonder hier te worden vermeld. Hebben wij tot dusverre drie soorten van familieinrichting op Sumatra leeren kennen, hier ontmoeten wij eene vierde, welke, staande tusschen het patriarchaat en het matriarchaat, gebaseerd is op de kinderverdeeling. De regel bij de Rajat-Laut is namelijk, dat de onevengeboren kinderen de moeder volgen en dus ook hare erfgenamen zijn, de evengeboren kinderen echter aan den vader behooren en zijne nalatenschap bekomen. Is het laatste kind een onevengeboren, zoodat, wanneer de adat werd gevolgd, de moeder één kind meer zou hebben dan de vader, dan wordt het eerst niet aan een der beide ouders toebedeeld, maar het kan later, als het tot de jaren des onderscheids gekomen is, zelf kiezen, wie het volgen wil. Zoolang die keuze niet is gedaan, zegt men dat zulk een kind mata malang, dat is, wat wij zouden zeggen, schele oogen, geeft $9 \mathbf{5}$. - Het systeem van de verwantschap gebaseerd op eene gelijke verdeeling der kinderen tusschen de ouders, bij de Rajat-Laut, is daarom zoo belangrijk, dewijl het, voor zoover onze kennis reikt, volledig nog alleen

${ }^{44}$ De Orang-Akit wonen hoofdzakelijk op het kusteiland Roepat, terwijl vroeger ook eenigen, de zoogenaamde Akit-Penguling, gevestigd waren aan den rechteroever van de monding der Siak. Dezen hebben echter hunnen grond verlaten, zijn de Siak opgevaren en houden zich nu op in de buurt van Koewala-Mandau, waar zij op vlotten op de rivier wonen (Hijmans van Anrooy, Siak Sri Indrapoera, blz. 350-352. Zie ook: blz. 302-303). Nog behooren volgens sommigen tot de OrangAkit, gelijk wij in noot 27 hierboven gezien hebben, de onderhoorigen van den batin van Prawang. De Orang-Rawa ontleenen hunnen naam aan de Soengei-Rawa, een riviertje dat ten Zuiden van de Siak in zee valt, waarlangs zij gevestigd zijn, tewijl de Orang-Utan gevonden worden op de kusteilanden in de nabijheid van de mondingen der Siak en Kampar (Hijmans van Anrooy, O. c., blz. 352). Al deze stammen, die, zooals reeds in den tekst is opgemerkt, gerekend worden tot de Rajat-Radja van Siak te behooren, zijn Heidenen (zie noot 25 hierboven), en staan nog op een lagen trap van beschaving. - De Rajat-Laut zijn vooral gevestigd langs de kust bij de Brouwerstraat, ongeveer ter hoogte van BoekitBatoe, ten Noorden dus van de uitwatering der Siak (Hijmans van Anrooy, 0.c., blz. 343). Zij behooren ook tot de Rajat-Radja, doch zijn al Mohammedanen.

95 Hijmans van Anrooy, Siak Sri Indrapoera, blz. 344. 
bij een tweetal andere stammen in den Indischen Archipel wordt aangetroffen, namelijk bij de Makassaren en Boegineezen. Ook bij hen behoort het eerste kind aan de moeder, het tweede aan den vader, het derde weder aan de moeder, het vierde aan den vader, enz. Anders echter dan bij de Rajat-Laut, is, bij een oneven aantal kinderen, het jongste gelijkelijk van beide ouders, hoewel de moeder het recht heeft dat overschietende kind, tegen betaling van eene som gelds aan den vader, zich toe te eigenen ${ }^{\mathbf{9 6}}$.

Wij zijn hiermede aan het einde van ons overzicht gekomen. "Dankbaar, maar niet voldaan", plegen recensenten te zeggen. "Dankbaar, maar niet voldaan", zeggen ook wij. Onze kennis van Sumatra is zeker in de laatste jaren buitengewoon vooruitgegaan, vooral door de onderzoekingen van de Ambtenaren bij het Binnen-

96 Zie uitvoeriger hierover onze verhandeling: Over de verwantschap en het huwelijks- en erfrecht bij de volken van het Maleische ras, blz. 69 vv. - Overigens zien wij de kinderverdeeling bij enkele volken nog alleen in bepaalde gevallen plaats hebben. Zoo voorheen bij de Tagala's van de Philippijnen bij een huwelijk buiten de barangai of het dorp. Bij voorkeur trouwde men in de barangai; was de vrouw echter van eene andere barangai dan de man, dan werden de kinderen tusschen de barangai's der ouders verdeeld (Blumentritt, Die Staaten der philippinischen Eingebornen in den Zeiten der Conquista, blz. 3). Misschien was oorspronkelijk wel het huwelijk buiten de barangai, en daarmede de kinderverdeeling, algemeene regel. Verder komt bij een paar volken, die de agnatische of patriarchale verwantschap bezitten, de kinderverdeeling voor, als er eene echtverbintenis zonder bruidschat gesloten wordt. Allereerst wijzen wij op de Pasěmahers. Dezen hebben het patriarchaat gepaard met de exogamie, in dien zin dat bewoners van hetzelfde dorp of dusun niet met elkander mogen trouwen. De kinderen behooren aan den vader en dus ook aan diens dusun, als de bruidschat volledig is opgebracht. Bij niet-betaling van den bruidschat echter, worden de kinderen - in afwijking van hetgeen elders gebeurt, waar zij in een dergelijk geval allen de moeder volgen gelijkelijk tusschen de verwanten der beide ouders verdeeld, zoodat zij voor de eene helft in het dorp van de vrouw, voor de andere in dat van den man verblijf houden (Zie onze zooeven aangehaalde verhandeling, blz. 64, en de daar aangehaalde bronnen). Ook bij de Savoeneezen bestaat de regel, dat, als er geen bruidschat betaald wordt, de kinderen gedeeltelijk aan den vader, gedeeltelijk aan de moeder behooren. Van drie kinderen bij voorbeeld zijn het eerste en het laatste kind dan bepaaldelijk van de moeder (Donselaar, Aanteekeningen over het eiland Savoe, Mededeel. v. w. h. Nederl. Zend. Genootsch., dl. XVI, blz. 312). - Dan nog zien wij hoe er wel eens eene kinderverdeeling plaats heeft bij gemengde huwelijken en bij echtscheidingen. Van het eerste zullen wij gelegenheid hebben, in het aanhangsel aan het slot van dit opstel, eenige voorbeelden bij te brengen. Wat de kinderverdeeling bij echtscheiding betreft, wij vinden die vooreerst bij de Redjangers. Dezen hebben de agnatische verwantschap: tegen voldoening van den volledigen bruidschat, bij het semendo-terdjun-pesuvi, volgen de kinderen den vader; als de bruidschat echter niet is opgebracht, bij het semendo-betanam5e Volgr. III. 
landsch Bestuur, onder wie de Heeren Van Rijn van Alkemade, Hijmans van Anrooy en Neumann met lof genoemd moeten worden. Doch aan den anderen kant zijn er - uit het in de voorgaande bladzijden medegedeelde kan dit ten aanzien van de verwantschap en het huwelijks- en erfrecht duidelijk geworden zijn - vele leemten in die kennis gebleven. Mogen dus niet alleen de genoemde Heeren, aan wie de wetenschap reeds zooveel verschuldigd is, doch ook anderen, welke daartoe in de gelegenheid zijn, zich opgewekt gevoelen, door hunne navorschingen, het ontbrekende of minder goed

batu, behooren zij aan de moeder. In latere tijden heeft echter, tusschen deze beide huwelijksvormen, een derde zich ontwikkeld, het zoogenarmde semendo-bidup-idup, waarbij er een kleine bruidschat hetaald wordt en de kinderen aan de beide ouders behooren. Misschien werden zij oorspronkelijk wel tusschen man en vrouw gelijkelijk verdeeld, evenals dit bij de Makassaren en Boegineezen en bij de Rajat-Laut het geval is. $\mathrm{Nu}$ heeft deze verdeeling echter alleen plaats bij echtscheiding. Is het aantal kinderen daarbij oneven, dan heet het jongste, niet toegewezen, kind merdika, vrij, en blijft voorloopig bij de moeder. Door haar eene som van acht rijksdaalders, de zoogenaamde wang-pesusahan, te betalen, krijgt de vader echter het recht dat kind, zoodra het de moederlijke zorgen niet meer behoeft, bij zich te houden en in zijne familie op te nemen (Van Hasselt, Volksbeschrijving van MiddenSumatra, blz. 292). Iets dergelijks treft men ook in Laboean-Batoe aan. Boven (blz. 189) zagen wij hoe het gewone huwelijk hier het semando is, waarbij de kinderen meer gerekend worden aan de moeder te behooren dan aan den vader, zoodat zij ook in geval van echtscheiding bij haar blijven. Daarnaast vindt men echter het in noot 78 genoemde huwelijk bij belandja, waarbij waarschijnlijk primitief de kinderen tussehen de beide ouders verdeeld werden. Evenals in Redjang, wordt echter nu nog alleen bij echtscheiding tot de verdeeling overgegaan: de jongens volgen dan den vader, de meisjes de moeder (Neumann, Schets der afdeeling Laboean-Batoe, Tijdschr. 'v. Ind. T. L. en Vk., dl. XXVI, blz. 459). Op eene vroegere kinderverdeeling wijst missohien de volgende bepaling, voorkomende in de "Abstract of some of the laws which, according to the tradition of the Javans, were in force against the inhabitants, previous to the supposed arrival of Aji Saka", door Raffles in zijn "History of Java" (dl. II, Appendix, blz. LIII) medegedeeld: "Lawfully married persons wishing to separate from each other, each retook the property brought at the marriage, and an equal division was made of what had been gained since the marriage. This included the ehildren; the eldest was always to remain with the mother, the second with the father. After the separation on the decease of either, the whole effects were to be taken possession of by those children who, at the separation, had come to the share of the deceased; but they were also obliged to pay the debts of the deceased, whatever the same might amount to. When the number of children was unequal, the odd one was to fall to the share of the wife; but such as were imperfect or deformed were excluded from the division, and maintained by both parties". Eindelijk moeten wij er op wijzen, hoe eene kinderverdeeling bij echtscheiding ook voorkomt bij de Papuwa's van Kaimani op de Zuidwestkust van Nieuw-Guinea. Evenals in Laboean-Batoe volgen dan de zoons den vader, de dochters de moeder (Nieuw-Guinea, ethnographisch en natuurkundig onderzocht en beschreven, blz. 126-127). 
bekende aan te vullen, het onjuiste te verbeteren. Dat men toch bedenke hoezeer er hierbij periculum in mora is. Men moet zich haasten de verschillende stammen, niet het minst die, welke, gelijk de Orang-Sakei, de Orang-Akit, de Orang-Utan en de Orang-Rawa, nog het Heidendom belijden, of, als de Orang-Talang en de RajatLaut, nog meer of min intact zijn gebleven, en dus bij uitnemendheid als de representanten eener primitieve beschaving te beschouwen zijn, te bestudeeren, eer het te laat is, en zij al hetgeen hun karakteriseert, al het oorspronkelijke verloren hebben, onder den alles nivelleerenden stroom eener Europeesche of Mohammedaansche cultuur. Moge op die wijze de wetenschap spoedig in staat zijn, onder meer, ook een volledig beeld te ontwerpen van de ontwikkelingsgeschiedenis der familie op Sumatra. 


\section{A A NHANGSEL.}

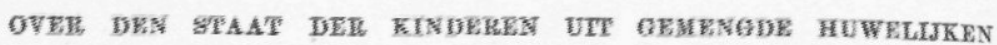

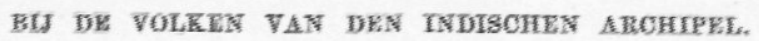

In mijne verhandeling "Over de verwantschap en het huwelijksen erfrecht bij de volken van het Maleische ras", voerde ik, als cen overblijfsel van het matriarchaat bij de Bataks, nog den regel san, bij het slavenrecht geldende, dat het kroost steeds den staat der moeder volgt. Bij een huwelijk toch tusschen een vrijen man en eene slavin is het kind slaaf, terwijl bij eene verbintenis tusschen eene vrije vrouw en een slaaf het kind vrij is. "Ten einde", aldus merkten wij nu op ${ }^{1}$, "de waarde van deze bepaling te begrijpen, houde men in het oog, dat er hier niet van eene rechtelooze vereeniging, van een concubinaat sprake is, doch van een geregeld huwelijk. Ware het eerste het geval, dan zou het voorschrift, dat het kroost de moeder volgt, volkomen op zijne plaats zijn. $\mathrm{Nu}$ echter kan het niet anders dan vreemd klinken, dat onder het stelsel van de vitsluitende afstamming in de mannelijke lijn, de vader, vrijgeborene, niet bij machte is, het kind door hem in wettigen echt bij eene slavin verwekt, tot zijnen stand op te heffen, terwijl de moeder, vrije vrouw, dit wel doen kan ten opzichte van het kind, dat zij bij eenen slaaf gekregen heeft. Ongetwijfeld hebben wij dan ook in deze bepaling slechts een overblijfsel te zien van eene oorspronkelijke matriarchale inrichting der familie". - Dies diem docet. Zoo heeft dan ook, gelijk ik hierboven in noot 93 reeds met een enkel woord deed uitkomen, een voortgezet onderzoek mij geleerd, dat wat ik zoozeer als een rechtstreeksch overblijfsel van het matriarchaat heb beschouwd, zich geheel uit de regelen van het patriarchaat verklaren laat. Ik stel mij voor, onder meer, dit in de volgende bladzijden kortelijk aan te toonen.

Het kan zeker in het algemeen gezegd worden, dat bij gemengde huwelijken de staat van het kind bepaald wordt door het heerschende verwantschapsstelsel. Bij het matriarchaat, om dit in de eerste plaats te noemen, regelt die zich naar de moeder: het is door de vrouw, dat zoowel de adel als de slavernij zich voortplant. Een paar

1 Zie de aangehaalde verhandeling, blz. 37 . 
voorbeelden mogen hier volstaan. Van de Lyciërs sprekende, die het matriarchaat beoefenen, zegt Herodotus: "Als eene vrije vrouw met eenen slaaf huwt, worden hunne kinderen gerekend van goede geboorte te zijn, maar als een vrije man met eene vreemde vrouw trouwt, hebben hunne kinderen, ook al ware hij de eerste persoon in den staat, volstrekt geen burgerrecht" ${ }^{2}$. Bekend is het dat bij de Berbers in Noord-Afrika de verwantschap gebaseerd is op de afstamming uitsluitend in de vrouwelijke lijn. Overeenkomstig daarmede heeft ook bij hen de vrouw het voorrecht van te adelen. "Le fils d'un père esclave ou serf et d'une femme noble est noble; le fils d'un père noble et d'une femme serve est serf; le fils d'un noble et d'une esclave est esclave" ' ${ }^{3}$. Bij de Negervolken van West-Afrika geldt dezelfde regel, als een uitvloeisel van de bij hen nog geldende matriarchale instellingen. In zijne "Nauwkeurige beschrijving van de Guinese Goud- Tand- en Slavekust" zegt Bosman daaromtrent: "Een ieder kiest hier een partuur na sijn sin, en het geeft geen ongelijk houwelijk, een konings dogter met een slaaf, zijnde nog beter als dat de soon eens konings een slavin trouwd (en dat geschied onvermijdelijk alle dage): want wijl volgens het gemeen seggen, de kinders de moeder volgen, gelijk hier mede gebruykelijk is, soo zijn de kinderen van* de eerste vrij, en de andere daar en tegen slaven" ". Van de volken van den Indischen Archipel wijzen wij, om een enkel sterk sprekend voorbeeld aan te halen, op de bewoners van Kisar, behoorende tot de Zuidwestereilanden. Dezen hebben het matriarchaat, hoewel niet meer volledig, doch reeds in het stadium van overgang tot de parentale verwantschap $^{5}$. Bij gemengde huwelijken nu volgen de kinderen den staat der moeder. Men heeft hier namelijk drie standen, de marna, de adel, de orang-bur, de volksklasse, en de slaven. Eene verbintenis

${ }^{2}$ Herodotus 1, 173.

${ }^{3}$ Duveyrier, Les Touareg du Nord, blz. 337.

4 Bosman , O. c., blz. 184.

${ }^{5} \mathrm{Wij}$ vinden namelijk op Kisar eenen toestand ongeveer als in de Djambisohe Bovenlanden, met name in de Batang-Hari-districten en in Korintji. De zusterskinderen erven nog alleen bij ontstentenis van eigen kinderen (Riedel, De sluiken kroesharige rassen tusschen Selebes en Papua, blz. 409). Ook in waardigheden volgen zonen hunnen vader reeds op. Alleen wanneer er geene zonen zijn, hebben de zusterszonen den voorrang boven de broerszonen (Riedel, O. c., blz. 406). Evenzoo zien wij uit het huwelijksverbod hoezeer bij de bewoners van Kisar, naast de moederlijke verwantschap, de vaderlijke begonnen is, zich te ontwikkelen. Verboden is namelijk niet alleen het huwelijk tusschen de kinderen van twee zusters, gelijk 
tusschen eene vrouw van hoogeren en iemand van lageren stand is op straffe des doods verboden; daarentegen is het toegelaten dat bij voorbeeld een marna-man eene vrouw van de orang-bur trouwt: de kinderen behooren dan tot den stand der moeder, tot de orang-bur dus ${ }^{6}$. Nog vindt men op Kisar eene andere klasse van ingezetenen, bestaande uit de afstammelingen van de Hollanders, welke vroeger op dit eiland gevestigd zijn geweest. Deze mestiezen, die zich door niets anders van de overige inlanders onderscheiden dan door hunne Europeesche familienamen, trouwen meestal onder elkander. "Ce n'est qu'exceptionnellement qu'une de leurs femmes est donnée en mariage à un homme d'une autre race, même, dans ce cas, les descendants conservent le nom de la mère, le nom hollandais" ? Ook in dit geval bepaalt dus de staat der moeder dien van het kind.

Regel is het dus dat onder het matriarchat het kind den staat der moeder volgt bij gemengde huwelijken. Hoe is dit nu onder het patriarchaat? A priori zou men zeggen, dat de staat van het kind zich hier moest regelen naar dien van den vader. Intusschen is dit niet zonder meer het geval. Gelijk men toch weet, is de agnatische of patriarchale verwantschap gebaseerd op gezag: het kind behoort aan den man, die heer der vrouw is. Heeft de man bij het huwelijk het gezag, de manus, het mundium, over de vrouw verkregen, dan zijn de kinderen van hem; is de vrouw integendeel in patria potestate gebleven, dan heeft hij niets over zijne kinderen te zeggen en behooren dezen tot het geslacht der moeder ${ }^{8}$. In het eerste geval regelt zich dus de staat van het kind naar dien van den vader, in het tweede naar dien der moeder. Zoo ook bij de volken van den Indischen Archipel. De wijze waarop hier het gezag over de vrouw verkregen wordt, is door den bruidschat te betalen. $\mathrm{Bij}$ de bewoners van de Watoebela-eilanden nu - om de zaak dadelijk met een voorbeeld toe te lichten - treft men drie standen aan, de tuntata of de adel, de tamansia of de volks-

dit het geval is waar het matriarchat nog in zuiveren vorm bestaat, doch ook dat tusschen de kinderen van twee broeders, zoodat alleen toegelaten zijn echtverbintenissen tusschen de kinderen van een broer en eene zuster (Riedel, 0. c., blz. 416 en 474).

6 Rinnooy, L'ancienne sous-résidence de Kisser, Revue coloniale internationale, jaarg. 1886 , dl. II, blz. 52.

7 Rinnooy, O. c., blz. 42.

$8 \mathrm{Zie}$ hierover onder anderen onze verhandeling : Oostersche en Westersche rechtsbegrippen, Bijdragen tot de T. L. en Vk. van Nederl. Indië, vijfde volgreeks, dl. III, blz. 127 vv. (overdruk blz. 7 vv.). 
klasse, en de ataa of slaven. Echtverbintenissen tusschen de twee eerste standen zijn geoorloofd. Is de bruidschat voldaan, dan is het kind van een tuntata-man en eene tamansia-vrouw, tuntata, van een tamansia-man en eene tuntata-vrouw, daarentegen tamansia. Door echter een huwelijk zonder bruidschat aan te gaan, kan in het laatste geval de vrouw het kind tot haren stand verheffen, hetgeen dan ook veelal gedaan wordt ${ }^{9}$. Een dergelijken regel vindt men eveneens op Ceram, Ceramlaoet en Boeroe: alleen door betaling van den bruidschat behoort hier het kind tot den stand van den vader ${ }^{10}$. Ook ten aarzien van het slavenrecht geldt hetzelfde beginsel, en het is alleen door de toepassing daarvan, dat, bij verbintenissen tusschen eene vrije vrouw en een slaaf of tusschen een vrijen man en eene slavin, het kind steeds de moeder volgt. Wij zullen dit nu speciaal bij de Bataks nagaan ${ }^{11}$.

Allereerst verdient het opgemerkt te worden, dat eene slavin door haren meester nooit tot bijzit mag worden genomen. Alleen aan hoofden is dit geoorloofd. Door zulk eene daad wordt de slavin vrij, terwijl de kinderen tot den stand van den vader behooren. Indien iemand, die geen hoofd is, gemeenschap heeft gehad met zijne slavin, wordt hij beboet met 54 realen; de slavin erlangt dan

9 Riedel, De sluik- en kroesharige rassen tusschen Selebes en Papua, blz. 194. Waar dus de agnatische verwantschap bestaat, kan de vrouw, door bij het huwelijk den bruidschat niet te ontvangen, met andere woorden door eene verbintenis zonder manus aan te gaan, het kind tot haren staat doen behooren, zoo zij de hoogere in rang is. Ziehier nu eene eigenaardige wijziging, die dit gebruik op de Ambonsche eilanden (Ambon en de Oeliasers) ondergaan heeft. Gelijk men weet, wordt de bevolking hier onderscheiden in burgers en negorijlieden, waarvan de eersten geacht worden hooger te staan. Voor zoover zij nu Christenen zijn, geschieden huwelijken bij deze beide standen ingevolge de verordening, door het Gouvernement uitgevaardigd bij Staatsblad van $1861, \mathrm{~N}_{0} 38$. Bij deze verordening is er natuurlijk geen sprake van een huwelijk met bruidschat en zonder bruidschat, cum manu en sine manu. Is de verbintenis gesloten ingevolge de bepalingen in dat Staatsblad vervat, dan volgen de kinderen den stand van den vader en moeten dus bij gemengde huwelijken, waarbij de vrouw van den burgerstand is, tot de lagere klasse der negorijlieden behooren. Ten einde dit nu te voorkomen, wordt in zulk een geval, tot het sluiten van den echt ingevolge de wettelijke bepalingen niet overgegaan, doch blijven man en vrouw in concubinat leven, waardoor de kinderen den naam van de moeder verkrijgen en haren staat volgen, burgers dus worden (Van Hoëvell, Ambon en meer bepaaldelijk de Oeliasers, blz. 134-135). Op de Ambonsche eilanden tracht men dus nu door het concubinat te verkrijgen, wat men vroeger verwierf door een huwelijk sine manu.

${ }^{10}$ Riedel, O. c., blz. 16, 101 en 154.

11 Hoofdzakelijk zullen wij hierbij gebruik maken van de belangrijke mededeelingen van den Heer Neumann, Het Pane- en Bila-stroomgebied, Tijdschr. v. h. Nederl. Aardr. Gen., 2e serie, dl. IV, blz. 36 vv. 
hare vrijheid en moet zich een waris of voogd zoeken. Hieruit blijkt dus dat de adat geen concubinaat met eene slavin erkent, doch alleen eene wettige verbintenis met haar toelaat. Verder moet hier nog op den voorgrond worden gesteld, dat niemand zijne eigen slavin mag huwen, tenzij met gelijktijdige vrijlating. De slavin deelt dan in alle rechten van eene wettige vrouw. Overigens zijn alle verbintenissen tusschen vrijen en onvrijen geoorloofd, hoewel die uit den aard der zaak weinig in aanzien zijn. Van eene vrije vrouw, die een slaaf huwt, zegt men, dat zij zich besmet heeft, en drukt dit uit met de woorden "galapang madabu tu bustak" letterlijk: de galapang ${ }^{12}$ is in den modder gevallen, terwijl het van een vrijen man, die zich met eene slavin verbindt, heet "ihan mangalumpat tu parau", dat is: (zoo dom als) een visch die in een vaartuig springt ${ }^{13}$. - Het huwelijk van eenen slaaf met eene vrije vrouw heeft steeds zonder bruidschat plaats. Dit ligt geheel in den aard der zaak, daar het betalen van den bruidschat gezag ten gevolge heeft en een onvrije dit niet over eene vrije kan hebben. De eigenaar, die voor zijn slaaf den koopprijs betaalt, de waris of voogd van de vrije vrouw, die hem van een slaaf vordert, de radja, die de betaling erkent, zijn zelfs strafschuldig. De misdaad is gelijk gesteld aan een moord, omdat, volgens de Bataksche uitdrukking, "een levende dood gemaakt wordt": de straf is de dood. De kinderen, die uit het huwelijk van eenen slaaf en eene vrije vrouw geboren worden, zijn van de moeder, volgen haren staat en hebben haren waris, voogd, tot waris. De slaaf-zelf wordt gezegd amang-ni-manuk, een vader van kippen, te zijn, waarmede men wil te kennen geven, dat er even weinig betrekking tusschen hem en zijne kinderen bestaat als tusschen een haan en zijne kiekens. - Bij een huwelijk tusschen een vrijen man en eene slavin kunnen zich twee gevallen voordoen. De eigenaar van de slavin kan namelijk eenen bruidschat voor haar eischen Deze geldt dan als losprijs voor de vrouw, die dus vrij wordt, terwijl de kinderen ook vrij zijn en aan den vader behooren. Wordt er geen bruidschat betaald, dan blijft de slavin natuurlijk in handen van

12 Een galapang is een schijfvormig stuk hout, dat aan de palen onder de woningen, doch vooral onder de rijstschuren bevestigd wordt, om te beletten dat de ratten naar boven klimmen.

13 Sommigen bezigen, onzes inziens echter minder juist, dit gezegde "ihan mangalumpat tu parau" met betrekking tot de slavin, omdat zij, door haar huwelijk met een vrijen man, op een hooger standpunt komt te staan, gelijk dit het geval is met een visch, die uit het water in een vaartuig springt. 
haren meester, terwijl de kinderen, den staat der moeder volgende en dus slaven zijnde, ook aan hem behooren ${ }^{14}$.

Het voorgaande samenvattende, zien wij hoe de drie volgende gevallen te onderscheiden zijn: 10 huwelijken tusschen eene vrije vrouw en een slaaf, waarbij geen bruidschat mag worden betaald, de kinderen aan de moeder behooren en den staat der moeder volgen, 20 huwelijken tusschen een vrijen man en eene slavin, zonder bruidschat, waarbij de kinderen den staat der moeder volgen en slaven zijn van haren heer, en 30 huwelijken tusschen een vrijen man en eene slavin tegen betaling van den bruidschat resp. losprijs aan den eigenaar, waarbij de kinderen den staat van den vader volgen. Ten anzien van het door ons behandelde vraagstuk, staat het laatste geval buiten het slavenrecht, daar toch bij het huwelijk de slavin, gelijk opgemerkt is, vrij wordt. Het blijkt dus dat, daar alleen de twee eerste gevallen in aanmerking mogen worden genomen, bij verbintenissen tusschen vrijen en onvrijen, zooals die in de praktijk zich kunnen voordoen, het "partus sequitur matrem" geldt, niet als een vooropgezet beginsel, rechtstreeks overgebleven uit het matriarchaat, doch blootelijk als uitvloeisel van den regel bij het patriarchaat, dat het kind, alleen bij betaling van den bruidschat, bij een huwelijk met gezag, met manus dus, den staat van den vader volgt, terwijl bij niet-betaling van den bruidschat, bij een huwelijk zonder manus, de staat zich naar dien der moeder regelt.

Het beginsel "partus sequitur matrem" geldt, gelijk bekend is, bij meer volken, die de patriarchale of agnatische verwantschap hebben, ten aanzien van het slavenrecht of in het algemeen van gemengde huwelijken. Niet onwaarschijnlijk is het, dat het bijhen, op dezelfde wijze als bij de Bataks, daaruit moet worden verklaard, dat dergelijke verbintenissen steeds zonder bruidschat, dat is zonder manus, gesloten worden. Zoo onder anderen bij de oude Romeinen. Alleen bij huwelijken tusschen personen, die het connubium hadden, volgden, zooals men weet, de kinderen den staat des vaders; waar geen connubium was, bij gemengde huwelijken, gold de regel "partus sequitur matrem". Bij eene verbintenis dus tusschen een civis Romanus en eene peregrina, was het kind een peregrinus, in het

\footnotetext{
14 De vader kan echter, van de verwekte kinderen, 'één jongen bij den rechter voor zich eischen. Wordt dit toegestaan, dan richt hij een gastmaal aan en verklaart als waris, voogd, van den jongeling op te treden. Nooit kan hij echter op die wijze meer dan één zoon voor zich bekomen, hoeveel kinderen hij ook bij de slavin heeft.
} 
omgekeerde geval, bij eene verbintenis tusschen eene civis Romana en een peregrinus, een civis Romanus ${ }^{15}$. Geheel overeenkomstig hetzelfde beginsel was ook het kind van een vrijen man en eene slavin, slaaf, van eene vrije vrouw en een slaaf, vrij ${ }^{16}$. Dit nu is zeker alleen daardoor te verklaren, dat ook bij de Romeinen, oorspronkelijk althans, het gezag over de moeder over het vaderschap besliste 16a , en een huwelijk, waarbij de man gezag over de vrouw verkreeg, slechts mogelijk was waar connubium bestond. Alleen personen toch, die het connubium hadden, konden een matrimonium justum aangaan ${ }^{\mathbf{1 7}}$, dat wil zeggen een huwelijk met in manum conventio ${ }^{17 \mathrm{a}}$. Waar geen connubium was, kon ook zulk een huwelijk niet plaats hebben, kwam de vrouw dus niet onder het gezag van den man en had deze geen recht op de kinderen, welke aan de familie der moeder behoorden en dus ook den staat der moeder volgden. Het beginsel "partus sequitur matrem" bij het gemengde huwelijk had dus zijn natuurlijken grond daarin, dat zulk een huwelijk steeds sine manu was, in tegenstelling van het matrimonium justum, het huwelijk waar connubium bestond,

15 Zoo was het oorspronkelijk. Later werd echter bij de Lex Minicia bepaald, dat bij gemengde huwelijken tusschen Romeinen en peregrini het kind den staat zou volgen van dengene der ouders, die het slechtste recht had. Ulpianus V, 8: "Connubio interveniente liberi semper patrem sequuntur; non interveniente connubio matris condicioni accedunt, excepto eo, qui ex peregrino et cive Romana nascitur; nam is peregrinus nascitur, quoniam lex Minicia ex alterutro peregrino natum deterioris parentis condicionem sequi jubet". Vergelijk ook: Rossbach, Untersuchungen über die römische Ehe, blz. 464 vlg.

16 Gajus I, 82: "Illud quoque his consequens est, quod ex ancilla et libero, jure gentium, servus nascitur, et ex libera et servo liber nascitur".

16a Zie hierover onze verhandeling: Oostersche en Westersche rechtsbegrippen, Bijdragen tot de T. L. en Vk. van Nederl. Indië, vijfde volgreeks, dl. III, blz. 133 vlg. (blz. 13 vlg. van den overdruk), en de daar aangehaalde plaatsen. Verder: ])argun, Mutterrecht und Raubehe und ihre Reste im germanischen Recht und Leben, blz. 9 vv.

17 Ulpianus V, 2: "Justum matrimonium est, si inter eos, qui nuptias contrahunt, connubium sit".

17a De manus werd, gelijk bekend is, oorspronkelijk althans, verkregen door confarreatio of door coemptio. De confarreatio was het patricisch gewijd of sacraal huwelijk, de coemptio de wereldlijke vorm, waarvan zich primitief de plebejers bedienden. Deze laatste bouwt op het recht des vaders om zijne kinderen te verkoopen. Men beliende zich van den oud-Romeinschen vorm van verkoop mancipatio, welke plaats greep ten overstaan van kooper, verkooper, vijf getuigen en den libripens, een onpartijdig persoon, die in vroeger tijd, toen de koopprijs werd toegewogen, noodig was. Bij de coemptio was de bruidegom kooper en kocht de bruid van haren vader of voogd, door met een geldstuk de schaal aan te raken. 
dat cum manu werd aangegaan. Die tegenstelling hield echter vanzelf op, het beginsel verloor daarmede zijn rechtsgrond en bleef alleen als eene overgeleverde leer voortleven, toen het later regel was geworden, dat het matrimonium justum ook zonder manus kon plaats hebben, terwijl de kinderen toch aan den vader behoorden $\mathbf{1 8}$.

18 Hetzelfde beginsel als bij de Romeinen dat vreemdelingen, tenzij het tegendeel is vastgesteld, geen connubium hebben, dat is dus geen huwelijk met manus mogen sluiten, vinden wij ook in den Indischen Archipel bij sommige volken, die de agnatische verwantschap bezitten. Een voorbeeld daarvan hebben wij boven (zie noot 81a) reeds leeren kennen bij de Atjehneezen. Hier wijzen wij in de eerste plaats op de bewoners van de Timorlaoet-eilanden. Bij hen mogen vreemdelingen geen echtverbintenissen aangaan tegen betaling van den gewonen bruidschat. Er heeft dus geen in manum conventio plaats, zoodat de vader geen recht heeft op de kinderen, doch dezen aan de moeder behooren en natuurlijk ook haren staat volgen (Riedel, De sluik- en kroesharige rassen tusschen Selebes en Papua, blz. 302). Een dergelijke regel geldt verder bij de Orang-Gaju op Sumatra. Vreemdelingen mogen alleen huwelijken zonder bruidschat, dat is zonder manus, sluiten, hebben dus ook het recht niet hunne vrouwen mede te nemen, terwijl de kinderen eveneens bij de moeder blijven (Van Langen, Bijdrage tot de kennis der Gajoe-landen, Tijdschr. v. h. Nederl. Aardr. Gen., dl. V, blz. 37). - Het spreekt overigens vanzelf dat wanneer bij de agnatische verwantschap tusschen twee stammen resp. twee staten A en B het connubium bestaat, dit in dien zin is, dat manus-huwelijken evengoed toegelaten zijn tussehen mannen van A en vrouwen van B, als omgekeerd tusschen mannen van B en vrouwen van A. Eene merkwaardige uitzondering op dezen regel ontmoet men echter bij de bewoners van het Portugeesch gedeelte van Timor. Ziehier hetgeen wij onder anderen in het werk van den Heer Forbes omtrent de "connubial relations" bij hen vermeld vinden. "To the west of Bibięuçu lies the neighbouring kingdom of Manufahi, and to the south-west that of Allas. The men of Manufahi cannot purchase wives from Bibiçuçu, but the men of Bibiçuçu can obtain wives by barter from Manufahi. The women of Bibiçuẹu can obtain husbands from Manufahi, if these men come and live during the lifetime of their wives in the kingdom of their wives. No purchasemoney may be paid, and none may be accepted for them". En verder: "Saluki and Bidauk are two districts of the kingdom of Bibiçuẹu. A man of Saluki may marry a woman of Bidauk, and take her back with him to Saluki; but he must purchase her, and it is not in his option te remain in Bidauk with his wife's relatives instead of paying for her. On the other hand, the men of Bidauk can marry with the women of Saluki; but the man must go to Saluki and live in the house of the woman, and he has not the option of paying for her at all. The children of the union belong to her, and on her death inherit all her property, while the husband returns to his own kingdom, leaving the children behind him, except in the case of their being more than two, when he is entitled to claim at least one". Deze regel bestaat evenwel niet tusschen alle dorpsstaatjes. "Also", teekent Forbes onder anderen nog aan, "as far as I am able to learn, Manufahi men may take wives from Allas - or Allas men from Manufahi - on paying the ordinary price demande 1 in these kingdoms for a wife, without incurring any restriction as to residence" (Forbes, A naturalist's wanderings in the Eastern Archipelago, p. 45.7). 
Behalve bij de oude Romeinen vinden wij bij de verschillende Germaansche volken, gelijk dit door Dargun, in zijn voortreffelijk werk "Mutterrecht und Raubehe und ihre Reste im germanischen Recht und Leben", met tal van voorbeelden is aangetoond, de bepaling "partus sequitur matrem", of gelijk het heet "das Kind folget dem Busen", bij gemengde huwelijken, vooral bij verbintenissen tusschen vrijen en onvrijen ${ }^{19}$. Ook de Skandinavische, vooral de Deensche, volksrechten, huldigden hetzelfde beginsel. "Entschieden tritt der Zusammenhang zwischen dem Stand der Mutter und dem der Kinder in dänischen Rechtsquellen hervor", lezen wij onder anderen in het werk van Dargun, "und wir stehen nicht an zu behaupten, dieselben hätten hierin einen altertümlicheren, ursprünglicheren Character bewahrt, denn das isländische; norwegische und schwedische Recht.... Andreas Sunesen sagt in seiner Paraphrase des schonischen Rechtes, dem ältesten Denkmal desselben: Matris conditionem sequitur semper partus, ut sit liber partus ex libero ventre procreatus, licet pater servili conditione premeretur. Ebenso bestimmt das Waldemar-Seeländische Gesetz: Ist die Frau frei, der Mann unfrei und hat er Kinder mit ihr, so sind die Kinder frei, und Andreas Sunesen an anderem Orte: Ut partus..... sit servus ex ventre servili progenitus, quantumcunque pater inter ingenuos nobilitatis genere praefulserit" 19a. - Niet minder verdienen de voorschriften van den Islâm omtrent huwelijken tusschen vrijen en onvrijen hier vermeld te worden. Evenals bij de Bataks,

19 Dargun, O. c., blz. 23 vv. Zie ook: Grimm, Deutsche Rechtsalterthümer, blz. 325 .

19a Dargun, O. c., blz. 39. Zie ook: Grimm, Deutsche Rechtsalterthümer, blz. 325. - Wat de voortplanting van den adel betreft, was het reeds spoe lig bij de Europeesche volken een algemeene regel, dat dit door den man geschiedde, zoodat bij huwelijken tusschen personen van adel en niet-adel het kind den staat van den vader volgde. Uitzonderingen hierop kwamen echter, zelfs tot in latere tijden, voor, bij voorbeeld, in Frankrijk, in Champagne en Barrois. "Il est certain", zegt in zijn "Précis de l'histoire du droit Français" onder anderen Viollet, "qu'au XIVe et au XVe siècle, la noblesse maternelle, e'est-à-dire la noblesse par la mère a été admise en Champagne. Grosley a cité à cet égard des textes décisifs. La noblesse maternelle était encore admise en quelques parties de la Champagne au XVIIIe siècle. La noblesse maternelle de Champagne a donné liou à diverses discussions et contestations; celle du Barrois n'a point été contestée. La transmission de la noblesse par la mère a donné lieu à ce dioton: (en Champagne et en Barrois), le ventre anoblit" (Viollet, 0. c., blz. 219). De vraag is echter in hoeverre dit beginsel "le ventre anoblit" een rechtstreeksch overblijfsel was van het matriarchaat, of zich, op analoge wijze als de regel "partus sequitur matrem" bij verbintenissen tusschen vrijen en onvrijen, onder de patriarchale verwantschap-zelve gevormd heeft. 
mag niemand zijne eigen slavin huwen, tenzij na voorafgaande onvoorwaardelijke vrijlating. De kinderen volgen dan natuurlijk den staat van den vader ${ }^{20}$. Overigens geldt bij het slavenrecht de regel "partus sequitur matrem": is de moeder vrij, dan zijn de kinderen het ook; is zij echter slavin, dan zijn de kinderen slaven van haren heer ${ }^{21}$. Zeer waarschijnlijk is deze bepaling van vóórIslâmschen oorsprong, en heeft zij zich, op analoge wijze als bij de Bataks, gevormd onder het patriarchale of agnatische verwantschapsstelsel, dat in de laatste tijden der djâhilîja, zoo niet overal, dan toch in de voornaamste streken van Arabië, moet hebben bestaan 22 .

Wij hebben in het voorgaande nu gezien, hoedanig de staat der kinderen uit gemengde huwelijken is onder de heerschappij van het matriarchat en van het patriarchat. De regelen, dus gevormd, bleven bestaan, ook toen die twee familieinrichtingen zich langzamerhand in het parentale verwantschapsstelsel hadden opgelost. Naarmate aan dit verwantschapsstelsel het matriarchaat dan wel het patriarchaat onmiddellijk is voorafgegaan, zullen dus ook bij gemengde huwelijken de kinderen den staat van de moeder of dien van den vader aannemen, behalve dat bij het slavenrecht, ook in het laatste geval, wel eens het beginsel "partus sequitur matrem" gelden zal. Overigens ontmoet men ten dezen nog andere bepalingen. Zoo is soms de regel van kracht, die echter zeker een product is van lateren tijd, dat het kind bij gemengde huwelijken "der ärgeren Hand" volgt, gelijk de oud-Duitsche rechtsboeken, waarin dit voorschrift voorkomt, het uitdrukken ${ }^{23}$. Ook bij de oude Romeinen werd, in afwijking van de oorspronkelijke bepaling "partus sequitur matrem", bij verbintenissen tusschen personen, die het connubium niet hadden, later bij de Lex Minicia bepaald,

${ }^{20}$ Van den Berg, Het Mohammedaansche recht, blz. 143. - Heeft een meester omgang met zijne slavin gehad en brengt zij hem dientengevolge een kind ter wereld, dan wordt zij omm-roalad, dat is zij geraakt buiten het handelsverkeer, mag dus niet meer verkocht of verpand worden, en is van rechtswege vrij bij den dood van den meester (Van den Berg, O. c., blz. 132-133 en 143). Ook bij de Bataks vindt men, gelijk wij gexien hebben, eene dergelijke bepaling: bij hen wordt echter de slavin onmiddelijk vrijgelaten.

21 Van den Berg, O. c., blz. 146.

${ }^{22}$ Zie hiervoor onder anderen onze verhandeling: Oostersche en Westersche rechtsbegrippen, Bijdragen tot de T. L. en Vk. van Nederl. Indië, 5e volgreeks, dl. III, blz. 129 vv. (blz. 9 vv. van den overdruk).

${ }^{23}$ Grimm, Deutsche Rechtsalterthümer, blz. 324. Zie ook: Dargun, Mutterrecht und Raubehe und ihre Reste im germanischen Recht und Leben, blz. 32. 
dat het kind den staat verkrijgen zou van dengene der ouders, die het slechtste recht had ${ }^{24}$. Bij de volken van den Indischen Archipel schijnt eene dergelijke bepaling niet te bestaan. Daarentegen vindt men hier veelvuldig den regel, die ook an het oud-Duitsche recht niet geheel en al vreemd was ${ }^{25}$, dat de kinderen voor de eene helft den staat van den vader, voor de andere dien van de moeder volgen. Wij wenschen volledigheidshalve dit nog na te gaan.

Gelijk vanzelf spreekt, moet men de hier bedoelde bepaling in de eerste plaats verwachten bij volken, wier geheele verwantschapsstelsel gebaseerd is op de kinderverdeeling, in het bijzonder dus bij de Makassaren en Boegineezen. Zelden gebeurt het bij hen, dat eene vrije vrouw met een slaaf trouwt, ja is eene dergelijke verbintenis zelfs verboden. Daarentegen komt het veelvuldig voor, dat een vrije man eene slavin huwt. In dit geval behoort het oudste kind aan de moeder en is slaaf, het tweede volgt den vader en is vrij, het derde komt weder aan de moeder toe en is slaaf, het vierde is het aandeel van den vader en is vrij, enz. ${ }^{26}$. Zoo volgt ook bij de Rajat-Laut in Siak, in overeenstemming met de bij hen op de kinderverdeeling berustende familieinrichting, bij gemengde huwelijken de helft der kinderen den staat des vaders, de andere helft dien der moeder. Bij eene verbintenis bij voorbeeld tusschen een Anak IV Suku en eene vrouw van de Rajat-Laut ${ }^{27}$, zijn de evengeboren kinderen Anak IV Suku, de onevengeboren Rajat-Laut ${ }^{28}$. Dezelfde regel bestond ook tijdens de conquista bij de Tagala's van Luçon, als een overblijfsel van den tijd, toen hunne geheele familieinrichting nog op de kinderverdeeling gebaseerd was 29. "Wenn ein Mahaldica (een vrije)", aldus lezen wij in eene verhandeling van den uitnemenden kenner der Philippijnen, Prof. Blumentritt ${ }^{30}$, "sich mit einer Sklavin (oder umgekehrt) vermählte, so folgten die Kinder gerader Zahl der Kaste des Vaters,

24 Zie noot 15 hierboven.

25 Grimm, Deutsche Rechtsalterthümer, blz. 325.

26 Zie onze verhandeling: Over de verwantschap en het huwelijks- en erfrecht bij de volken van het Maleische ras, blz. 69 .

${ }^{27}$ In het gebied van de Rajat-Laut te Boekit-Batoe zijn namelijk ook leden van de Anak IV Suku gevestigd.

28 Hijmans van Anrooy, Siak Sri Indrapoera, T. v. Ind. T. L. en Vk., dl. XXX, blz. 317,322 en 334 .

29 Zie noot 96 boven.

so Ueber die Staaten der philippinischen Eingebornen in den Zeiten der Conquista, blz. 6. 
jene der ungeraden Zahl aber dem Stande der Mutter ${ }^{30_{a}}$, wenn nun solche in einer Mischehe vereinigten Eltern nur ein Kind oder eine ungerade Anzahl von Nachkommen hinterliessen, so war dieses eine oder das letzte Kind ein Halbsklave". Tot welke eigenaardige verhoudingen de consequente toepassing van dezen regel moest leiden, leeren wij onder anderen op eene andere plaats in Blumentritt's verhandeling. Huwelijken hadden bij de Tagala's namelijk ook plaats tegen betaling van den bruidschat. Door niet-voldoening hiervan, kon de jonge echtgenoot in den toestand van tijdelijke lijfeigenschap bij zijne schoonouders komen, en het zelfs beleven, dat hij zijne eigen kinderen als slaaf moest dienen, "wenn widrige Verhältnisse, schwere Schicksalsschläge oder die Habsucht seines Schwiegervaters es ihm unmöglich machten, sich wieder aus dem Stande der Sklaven in die Kaste der Freien herauszuarbeiten". "Wir wissen nämlich bereits", aldus gaat Blumentritt voort, "dass die Kinder eines aus Sklaven und Freien zusammengesetzten Ehepaars theils Sklaven, theils Freie wurden. Blieb nun der Catipado ${ }^{31}$ im Sklavenstande, so war ein Theil seiner Kinder ebenfalls dem Sklavenstande angehörig, während andere Kinder dem Stande der Mutter folgend frei blieben. Starb der Schwiegervater, dem bisher der Schwiegersohn und ein Theil seiner Enkel als Sklaven gedient hatten, so wurden die freigeborenen Enkel die Herren ihres Vaters und ihrer Brüder. Wir wollen hoffen, dass in einem solchen Falle die freien Söhne von ihrem Rechte keinen Gebrauch machten, sondern den Vater und die Geschwister von dem Joche der Sklaverei befreiten" 32 .

Van de andere volken van den Archipel noemen wij in de eerste plaats de bevolking van Sumbawa, bepaaldelijk van het rijk van dien naam. Onder de standen, waarin het volk hier verdeeld is, behoort ook de zoogenaamde açal-ai-kuning, die eene soort van lageren adel vormt. Wanneer nu iemand van deze açal-ai-kuning met eene vrouw uit de tau-djuran of de tau-kamutar, de volksklasse, trouwt, volgen al de kinderen de moeder, zoo er geen bruidschat, paběli, betaald is. Heeft dit echter plaats gehad, dan worden de kinderen verdeeld. Niet echter als bij de Makassaren en Boegineezen, de RajatLaut en de Tagala's, behoort het oudste kind aan de moeder, doch aan den vader en is dus, evenals deze, açal-ai-kuning; het tweede kind vervalt aan de moeder en wordt tau-djuran of tau-kamutar, al

\footnotetext{
s0a Er staat "dem Stande des Vaters", hetgeen blijkbaar een lapsus calami is.

${ }^{31}$ Zoo heette de echtgenoot, "der den Brautpreis durch Sklavendienste abarbeitete".

s2 Blumentritt, 0. c., blz. 10.
} 
naardat de moeder tau-djuran of tau-kamutar is; het derde kind behoort weder tot de açal-ai-kuning, enz. Is er een oneven aantal kinderen, dan wordt het jongste voorloopig aan den vader toegewezen en dus onder de açal-ai-kuning opgenomen. Als echter later dit kind, volwassen geworden, trouwt, worden de kinderen, die dan geboren worden, onder de twee standen verdeeld ${ }^{3}{ }^{3}$. - Verder treft men nog den regel, dat bij huwelijken tusschen vrijen en onvrijen de kinderen voor de helft den stand van den vader, voor de andere helft dien der moeder volgen, bij de Bolaäng-Mongondouërs en de stammen van Centraal-Celebes aan. "Krijgt", aldus lezen wij van de eerstgenoemden, "eene slavin kinderen bij een vrijen man, dan wordt de helft der kinderen het eigendom van den meester der slavin, terwijl de overigen vrij zijn, indien de vader den door den eigenaar vastgestelden bruidschat betaald heeft..... Bij een oneven getal, wordt door eene der partijen eene som tot lossing van het overschietende kind opgebracht" ${ }^{\mathbf{3 4}}$. Bij de stammen van Centraal-Celebes vindt men de bepaling, dat wanneer bij eene batua- of slavenvrouw door een kabusenja of ingkai, iemand van adel, eene dochter verwekt wordt, deze den stand van den vader volgt, terwijl een zoon den stand der moeder aanneemt, tenzij de vader hem vrijkoopt ${ }^{35}$. Iets dergelijks geldt ook op het eiland Leti. Kinderen van een mara- of marna-man, iemand van adel, bij eene vosuru, vrouw uit de volksklasse, komen, wat de meisjes betreft, in den stand van den vader, en wat de jongens aangaat, in dien der moeder ${ }^{36}$. - Het zou zeker voorbarig zijn, uit de bestaande regeling te willen concludeeren, dat ook bij de laatstgenoemde volken de geheele familieinrichting eenmaal op dezelfde wijze op de kinderverdeeling gebaseerd is geweest, als

s3 Ligtvoet, Anteekeningen omtrent den economischen toestand en de ethnographie van het rijk van Sumbawa, Tijdschr. v. Ind. T. L. en Vk., dl. XXIII, blz. 559. Gelijk men weet, is Sumbawa voorheen onderworpen geweest aan het Makassaarsche rijk, en hebben, gelijk de Heer Ligtvoet opmerkt (O. c., blz. 556), de Sumbawaneezen ten allen tijde eene sterke zucht getoond, om de zeden en gebruiken der Makassaren na te volgen. Het is nu zeer de vraag, of de in den tekst besproken regeling ook niet door hen van hunne overheerschers overgenomen is. Zoo ja, dan hebben zij dat toch niet geheel onveranderd gedaan, hetgeen blijken kan $1^{0}$ uit het feit, dat de onevengeboren kinderen bij hen den vader volgen, en $2^{0}$ uit de eigenaardige wijze, waarop bij een oneven aantal kinderen gehandeld wordt.

34 N. P. Wilken en J. A. Schwarz, Allerlei over, het land en volk van BolaanngMongondou, Mededeel. v. w. h. Nederl. Zend. Genootsch., dl. XI, blz. 383.

35 Riedel, De oorspronkelijke volksstammen van Centraal-Selebes, Bijdragen tot de T. L. en Vk. van Nederl. Indië, vijfde volgreeks, dl. I, blz. 82.

s6 Riedel, De sluik- en kroesharige rassen tusschen Selebes en Papus, blz. 384. 
dit nu nog het geval is bij de Makassaren en Boegineezen en bij de Rajat-Laut. Wat de Letineezen betreft, kan men zelfs zeggen, dat zulk eene conclusie zeker onjuist is. Het verwantschapsstelsel bij hen beantwoordt toch in de hoofdzaken aan het matriarchaat ${ }^{37}$. Bij gemengde huwelijken zouden dus eigenlijk alle kinderen tot den stand der moeder moeten behooren. Bijzondere redenen hebben zeker tot afwijking van dezen regel aanleiding gegeven ${ }^{3 \mathbf{8}}$. In allen gevalle blijkt daaruit, dat zoo het hierboren opgemerkte in het algemeen juist is, dat namelijk bij verbintenissen tusschen personen van verschillende standen, de staat van het kind door het heerschende verwantschapsstelsel bepaald wordt, uitzonderingen daarop toch ook voorkomen.

Alvorens te eindigen, nog eene enkele opmerking. Gelijk uit het medegedeelde blijkt, bestaat er connubium tusschen de verschillende standen, zelfs tusschen vrijen en onvrijen. Toch kan het gezegd worden, dat over het algemeen ongelijke verbintenissen weinig in aanzien zijn, ja afgekeurd worden. Van de Bataks hebben wij dit hiervoren al gezien. "Galapang madabu tu bustak", een in den modder gevallen galapang, of "ihan mangalumpat tu parau", zoo dom als een visch, die in een vaartuig springt, heet het bij hen

${ }^{37}$ Dat op Leti de inrichting der verwantschap in de hoofdzaak aan het matriarchaat beantwoordt, blijkt in de eerste plaats uit het feit, dat de kinderen de moeder, dat is dan de familie der moeder, volgen (Riedel, De sluik- en kroesharige rassen tusschen Selebes en Papua, blz. 395, regel 1 v. o., en de verbetering daarop op blz. 474). Verder vinden wij een bewijs van het matriarchaat in het bestaande huwelijksverbod. Terwijl namelijk verbintenissen tusschen de kinderen van een broer en eene zuster of tusschen de kinderen van twee broeders toegelaten zijn, zijn die tusschen de kinderen van twee zusters verboden (Riedel, O. c., blz. 385 en 474). Verder wijst de erfopvolging van de zusterskinderen, zoo niet in bezittingen, dan toch in priesterlijke en andere waardigheden (Riedel, O. c., blz. 375 en 383. Zie ook noot 71 hierboven), op eene afstamming in de vrouwelijke lijn.

${ }^{38}$ Zoo wordt de zaak ook door Dr. Riedel voorgesteld. De door hem medegedeelde reden, waarom de kinderverdeeling zou zijn ingevoerd, kan echter, onzes inziens, bezwaarlijk de juiste zijn. Volgens hem zou dit namelijk geschied zijn, om de gemengde huwelijken tegen te gaan (Riedel, O. c., blz. 384). Doch dergelijke huwelijken kunnen alleen plaats hebben tussehen een man van hoogeren en eene vrouw van lageren rang, terwijl het omgekeerde, gelijk straks in den tekst zal blijken, niet geschieden mag. Nu ligt het voor de hand dat, daar naar de regelen van het matriarchant, die hier oorspronkelijk moeten hebben gegolden, al de kinderen de moeder volgden, door de invoering van eene kinderverdeeling, zulk een gemengd huwelijk voor den man voordeeliger werd gemaakt, dewijl nu althans de dochters tot zijnen stand behoorden. De matregel moet dus het sluiten van verbintenissen met vrouwen van lageren rang eerder in de hand gewerkt, dan beperkt hebben.

5e Volgx. III. 
van de vrije vrouw, die met een slaaf, resp. den vrijen man, die met eene slavin trouwt. Ook bij andere volken vindt men dergelijke spreekwijzen ter bespotting van hen, welke beneden hunnen stand een huwelijk aangaan, vooral van vrijen, die zich met onvrijen verbinden. "Meikatijon witum panga pěra", dat is: hij (of zij) is door een dorren tak gegrepen, zegt men in dat geval bij de Alfoeren der Minahasa ${ }^{39}$.. Bij de Koeteineezen vergelijkt men den vrijen man, die eene vrouwelijke sapangan (iemand die bij den vorst in slavernij zich bevindt ter zake van eenig vergrijp) huwt, bij een kiekendief die op een lijmstok neerstrijkt, "b̌nia měněrdjuni pulut", gelijk het gezegde luidt, terwijl het van eene vrije vrouw, die met een sapangan trouwt, heet "karbau masuk kandang", de buffel gaat de kraal binnen ${ }^{40}$. - Niet altijd is eene verbintenis tusschen personen, tot verschillende standen behoorende, onvoorwaardelijk toegelaten, doch mag die alleen plaats hebben, als de man de hoogere in rang is. Zoo is dit, gelijk wij hiervoren gezien hebben, bij de bewoners van Kisar het geval 41. Ook bij de Makassaren en Boegineezen vindt men denzeifden regel, zooals uit het boven angevoerde mede kan zijn gebleken. Terwijl huwelijken tusschen een vrijen man en eene slavin, in het algemeen tusschen iemand van hoogeren stand en eene vrouw van lagere afkomst, geoorloofd zijn en niet zelden voorkomen, mag het omgekeerde niet geschieden. Het is vooral bij vorstelijke familiën, dat geen meisje trouwen mag, alvorens het na een zorgvuldig onderzoek is uitgemaakt, dat haar aanstaande echtgenoot minstens haar volkomen gelijke in geboorte is ${ }^{42}$. Verder hebben wij

${ }^{30}$ N. P. Wilken, Spreekwoorden en eigenaardige spreekwijzen in het Tombulusch, blz. 6, No 28 (Bijdragen tot de T. L. en Vk. van Nederl. Indië, derde volgreeks, dl. V, blz. 200).

40 Tromp, Uit de salasila van Koetei, Bijdragen tot de T. L. en Vk. van Nederl. Indië, vijfde volgreeks, dl. III, blz 84, aanteekening 64 .

41 Zie blz. 202 boven.

42 Zie onze verhandeling: Plechtigheden en gebruiken bij verlovingen en huwelijken bij de volken van den Indischen Arohipel, blz. 15, en de daar in noot 51 geciteerde bronnen. - Eene uitzondering op het in den tekst medegedeelde maken, gelijk bekend is, de Boegineezen van het rijk Wadjo. Bij hen komt een huwelijk van iemand van lagere af komst met eene vrouw van adel, zelfs met eene vorstin, niet zelden voor. Een noodzakelijk vereischte daarbij echter is, dat de man zich als het ware edel bloed koope, dat wil zeggen der adellijke dame eene door haarzelve te bepalen som gelds ter hand stelle, ten einde haar in rang gelijk te worden, zooals uit de benamingen van die som blijkt, namelijk pangělli-dara, dat is: koopprijs van (edeler) bloed, of ovang-paenré, letterlijk: geld tot verheffing (van rang). Zie onze zooeven aangehaalde verhandeling, blz $15-16$, en de daar in noot 52 geciteerde plaatsen. 
hiervoren opgemerkt, hoe ook bij de Letineezen en de stammen van Centraal-Celebes mannen van rang met vrouwen van lageren stand zich verbinden kunnen. Het omgekeerde echter is bij beide volken verboden ${ }^{43}$. In Centraal-Celebes wordt de kabnisenja-vrouw, de vrouw van hoogen adel, die gemeenschap gehad heeft met een ingkai, iemand van lageren adel, een tausonda, een man uit de volksklasse, of een batua, een onvrije, beboet, terwijl haar medeplichtige met zijne geheele familie tot den slavenstand veroordeeld, of, zoo hij een batua is, zonder vorm van proces ter dood gebracht wordt ${ }^{44}$. Ook op Boeroe mogen mannen van hoogen stand met vrouwen van lage afkomst trouwen, niet omgekeerd ${ }^{45}$. - Bij enkele volken bestaat volstrekt geen connubium tusschen de verschillende standen, zijn alle verbintenissen verboden tusschen personen van ongelijke geboorte. Zoo bij de bewoners van Kei en Babar ${ }^{46}$, terwijl ook bij de Soembaneezen met de grootste strengheid er op gelet wordt, dat de aanstaande echtgenooten van denzelfden rang zijn : kinderen van hen, die een huwelijk boven of beneden hunnen stand hebben gesloten, worden niet zelden tot slaven veroordeeld ${ }^{47}$.

4s Zie: Riedel, De sluik- en kroesharige rassen tusschen Selebes en Papua, blz. 384, en De oorspronkelijke volksstammen van Centraal-Selebes, Bijdragen tot de T. L. en Vk. van Nederl. Indië, vijfde volgreeks, dl. I, blz. 82-83.

44 Riedel, De oorspronkelijke volksstammen van Centraal-Selebes, t. a. p.

45 Riedel, De sluik- en kroesharige rassen tusschen Selebes en Papua, blz. 16.

46 Riedel, O. c., blz. 228-229 en 346.

47 Roos, Bijdrage tot de kennis van taal, land en volk van Soemba, Verhandelingen v. h. Bat. Gen. v. K. en W., dl. XXXVI, blz. 49. 